UNITED STATES DEPARTMENT OF THE INTERIOR

Harold L. Ickes, Secretary

GEOLOGICAL SURVEY

W. C. Mendenhall, Director

Bulletin 925-B

\title{
GEOPHYSICAL ABSTRACTS 101
}

\author{
APRIL-JUNE 1940
}

COMPILED BY

W. AYVAZOGLOU

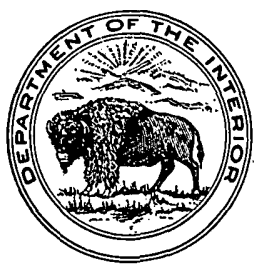

UNITED STATES

GOVERNMENT PRINTING OFFICE

WASHINGTON : 1941

For sale by the Superintendent of Documents, Washington, D. C. - . - . - - Price 10 cents 


\section{CONTENTS}

1. Gravitational methods

2. Magnetic methods

3. Seismic methods

4. Electrical methods

5. Radioactive methods

6. Geothermal methods

7. Geochemical methods.

8. Unclassified methods and topics related to geophysics

9. New publications...... 79

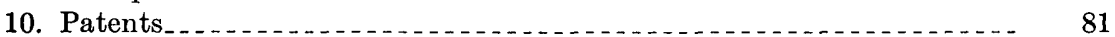

Index

Note.-Geophysical Abstracts 1-86 were issued in mimeographed form by the Bureau of Mines; Abstracts 87-100 were published in bulletins of the Geological Survey.

II 


\section{GEOPHYSICAL ABSTRACTS 101, APRIL-JUNE 1940}

\section{Compiled by W. Ayvazoglou}

\section{GRAVITATIONAL METHODS}

5454. Bornhauser, Max, and Marshall, L. R., Three new interior salt domes in northeast Louisiana: Am. Assoc. Petroleum Geologists Bull., vol. 24, No. 3, pp. 483-486, Tulsa, Okla., 1940.

In the course of an extensive gravimetric survey in northeastern Louisiana in 1937 the Continental Oil Co. mapped several pronounced gravity anomalies, three of which it has since tested by well borings. In each anomaly the first test led to the discovery of a new salt dome. The authors illustrate the approximate locations of the new domes and their relation to other known domes and structures in this area. They give a brief historical review of these domes (Singer dome, Madison Parish; Newellton dome, Tensas Parish; and Gilbert dome, Franklin Parish) and a summary of the stratigraphic section encountered in each discovery.W. A.

5455. Eckhardt, E. A., Gravity method produces results at low cost: Oil Weekly, vol. 97, No. 5, pp. 71-75, Houston, Tex., 1940.

The author discusses the development of the gravity method of prospecting under the following heads: (1) First gravity survey; (2) first in United States; (3) first commercial application; and (4) gravimeter. He considers the reflection seismograph, the torsion balance, and the gravimeter, and he presents in the form of a graph statistics as to the fluctuation of geophysical activity during the period 1935-39 in States bordering the Gulf of Mexico. The graph shows clearly the replacement of the torsion balance by the gravimeter. Concerning results, the author says: "Adequate data as to what discoveries are to be credited to gravity prospecting are not available. That they are substantial cannot be doubted. It can now be reported that in the first half of 1937 a gravimeter survey made with two instruments yielded discoveries averaging one per week for a string of over 20 wells, at a cost not greatly exceeding a few thousand dollars for geophysical work and lease bonuses for each prospect. This record can probably not be approached by any other prospecting technique." $-W . A$.

5456. Fischer, J. W., An experimental device for computing magnetic and gravitational anomalies: Geophysics, vol. 5, No. 1, pp. 22-30, Menasha, Wis., 1940.

Based upon the fact that gravitational and magnetic anomalies are: functions of the solid angle subtended at the point of measurement by the contours of the anomalous body, an electromagnetic model is described which permits direct measurement of the desired quantities in: 
terms of mutual inductance. A model of the subsurface "structure" is made in the form of a coil in which the vertical spacing of the turns is kept constant and the shape of the helix conforms to the contours of the structure. A small search coil is then located at the point corresponding to that at which a gravimetric or magnetometric observation is desired. The mutual inductance between the search coil and the main coil is then measured and may be expressed in terms of the magnetic or gravity anomaly arising from the simulated structure. For magnetic anomalies the search coil is made as compact as possible, whereas in the case of gravity anomalies the search coil is in the form of a long solenoid of small diameter, evenly wound along its length, in order to effect the integration necessary to measure the magnetic potential analogous to the desired gravitational quantity.-Author's abstract.

5457. Goudey, Raoul, Mesures de l'intensité de la pesanteur en France pendant l'anée 1939 [Measurements of the intensity of gravity in France during 1939]: Acad. sci. Paris Comptes rendus, vol. 210, No. 4, pp. 140-141, 1940.

Values of the intensity of gravity at 41 stations in France are shown in a table. Measurements were made with Holweck-Lejay gravimeters. $-W . A$.

5458. Haalck, Hans, Ưber die Bestimmung der Höhe bei Schwerekraftmessungen [On determining the altitude in making gravity measurements]: Beitr. angew. Geophysik, vol. 8, No. 1, pp. 1-10, Leipzig, 1939.

The mean error of $\Delta g_{0}{ }^{\prime \prime}$, a value used in practical geophysics for the determination of gravitational anomalies, is discussed. Special attention is given to the accuracy of $\Delta g_{0}{ }^{\prime \prime}$ as a function of the mean error in the determination of altitude. The measuring of altitudes by means of the barometric method is discussed, and the accuracy which may be obtained by this method is shown in a number of practical examples.Author's abstract.

5459. Jung, Karl, Zur Bestimmung von Störungsmassen aus Anomalien der Schwereintensitat [Determination of disturbing masses from anomalies of the intensity of gravity]: Beitr. angew. Geophysik, vol. 8, No. 1, pp. 11-17, Leipzig, 1939.

Jung has derived a simple geometrical method of determining subterranean disturbing masses from anomalies of the intensity of gravity. He discusses the sphere of application of the method.-W. $A$.

5460. Reich, Hermann, Closs, H., and Schoene, Hans-Joachim, Utber magnetische und gravimetrische Untersuchungen am Kaiserstuhl [On magnetic and gravimetrical investigations in the Kaiserstuh]]: Beitr. angew. Geophysik, vol. 8, No. 1, pp. 45-77, Leipzig, 1939.

Earth-magnetic and gravitational investigations in the plain southwest of the Kaiserstuhl Mountain, carried out during the exploration for. oil, led to remarkable results in regions thus far not sufficiently known by surface geology or by drilling. The "Tuniberg" fault does not continue to the Kaiserstuhl Mountain but is replaced by a northwestsoutheast striking fault (Rennmattenstörung), following the southwest edge of the mountain. West of the Tuniberg fault the existence of a "graben" could be proved which is partially filled up with young volcanic material. Some structural features could be traced to the south of the Tuniberg. The investigation is an interesting example showing how gravitational measurements may be completed by magnetic investigations in cases where magnetized rocks are involved. Furthermore, 
this geophysical work resulted in obtaining valuable data referring to the regional geology of the Kaiserstuhl Mountain and its surroundings.Authors' abstract.

5461. Schander, Johannes, Utber Schwerewirkungen von Salzstöcken [Gravity effects caused by salt domes]: Oel und Kohle, vol. 35, No. 41, pp. 756-759, Berlin, 1939.

Typical gravity profiles of German and American salt domes are shown for comparison. A detailed gravity picture of the Lüneburg salt dome and its surroundings is given, and the relation between this picture and the geologic formations is discussed. From a comparison of the gravity profile with the geologic profile the author concludes that details of the structural formations may be obtained if a sufficiently dense net of gravimeter stations is used. A Thyssen gravimeter mounted in a passenger automobile was very useful in making measurements within the limits of the city of Lüneburg.-W. $A$.

5462. von Zwerger, Rudolf, Aufsuchung und Umgrenzung schleswig-holsteinischer Salzaufbrüche mit Hilfe gravimetrischer Verfahren [Prospecting for and delimiting of Schleswig-Holstein salt domes with the aid of gravimetrical methods]: Oel und Kohle, vol. 35, No. 41, pp. 731-739, Berlin, 1939.

Salt domes in Holstein were systematically explored with the torsion balance after a regional gravimetric investigation. Decisive gravity disturbances that were established during the prospecting for and delimiting of the Holstein Zechstein salt domes are explained, and the results of torsion-balance measurements in the western part of Holstein are clearly summarized on a map. The discussion of geologic and physical relations proves that the survey that has been made forms an excellent foundation for a special complementary gravimetric investigation, from which the course and structure of important oil-bearing flanks of the domes may be obtained at comparatively small expense. Because of the great variety of the geologic causes of gravity disturbances, deep drilling should be added, if possible.-Author's abstract, translated by W. A.

5463. von Zwerger, Rudolf, Bau des Untergrundes des östlichen Eiderstedt auf Grund der Schwerestörungen im Bereich der Messtischblätter Tönning, Simonsberg und Husum [Underground structure of the eastern Eiderstedt, based on gravity disturbances within the area covered by the surveyor's plan sheets of Tönning, Simonsberg, and Husum]: Beitr. angew. Geophysik, vol. 8, No. 1, pp. 85-133, Leipzig, 1939.

Zechstein, Cretaceous boulders, and red clay marl were encountered by superficial drilling near Oldenswort. The red clay marl formations were interpreted by H. L. Heck as being Permian bedrock, while other scientists considered the red beds as having been transported as glacial drift from the northeast. Torsion-balance measurements proved the existence of a broad uplift striking from the mouth of the Eider for about 20 $\mathrm{km}$. to the north-northeast. The northern deeply buried part of the uplift (near Husum) is separated from the southern shallow part (between the Eider and Oldenswort) by a transverse fault, thus appearing as an individual structure. Maps showing gradients, curvatures, and isogams display the regional gravitational position of the structure as well as the individual anomalies of gravity which made the geophysical mapping of the structure possible. Gravitational and seismic results are compared. The geologic causes of this intricate type of gravity anomaly (quite 
different from the Hannover type of salt-dome anomaly) are discussed, and the importance of the investigations for the purposes of oil geology is stressed.-Author's abstract.

5464. Wolff, Wilhelm, Über Drehwaagenmessungen am Salzstock von Gifhorn [Torsion-balance measurements at the Gifhorn salt dome]: Oel und Kohle, vol. 35, No. 41, pp. 750-755, Berlin, 1939.

The Gifhorn salt dome is one of many domes in the north German lowland that were discovered and outlined exclusively by geophysical methods. First indications of the existence of this salt dome were obtained from torsion-balance measurements as early as 1927-29. The existence of this salt dome was confirmed in 1933 by a seismic survey and an outline was made of the position of the dome.

In this article the author gives details concerning the results of measurements carried out since 1934, which are illustrated by (1) a map of gradients at Gifhorn and its surroundings; (2) a map showing the values of curvatures; (3) gravity isogams; (4) profiles of gravity curves; (5) a structural map of the Gifhorn salt dome based on torsionbalance measurements and a seismic survey; and (6) gravity isogams obtained from measurements made with a Thyssen gravimeter. A general map based on the information obtained shows the salt-dome structure of the region about Gifhorn.-W. $A$.

5465. Zamorev, A. A., On the definition of derivatives of the gravitational potential and of the relations between the moments of perturbing masses by a derivative given on a plane [in Russian]: Acad. sci. U. R. S. S. Bull., sér. géog. et géophys., No. 3, pp. 275-286, Moscow, 1939.

Formulas are derived for calculating, from the values of a derivative given on a plane, the potential and its other derivatives in the outer semispace containing no perturbing masses. The method, as described, is based on the transformation into series, according to spherical and trigonometric functions, of Green's well-known formula and on the utilization of properties of the resolutions of the potential.

The paper contains also formulas for a cylindrical body extending to infinity (logarithmic potential).-W.A.

\section{MAGNETIC METHODS}

5466. Bein, G., Magnetische Messungen in den Eisenerzgebieten des Ostsudetenlandes [Magnetic measurements in the iron-ore fields of the eastern Sudeten district]: Beitr. angew. Geophysik, vol. 8, No. 1, pp. 134-141, Leipzig, 1939.

Several profiles of the anomalies of the vertical magnetic intensity over the magnetite-bearing iron ores of the eastern Sudeten district show the applicability of the magnetic method for tracing iron-ore trends in that region.-Author's abstract.

5467. Éblé, Louis, and Gibault, Gaston, Valeurs des éléments magnétiques à l'Observatoire de Chambon-la-Forêt (Loiret) au $1^{\text {er }}$ janvier. 1940 [Values of magnetic elements at the Chambon-la-Forêt (Loiret) Observatory on January 1, 1940]: Acad. sci. Paris Comptes rendus, vol. 210, No. 11, pp. 409-410, 1940.

Values of magnetic elements on January 1, 1940, were calculated from all the hourly values recorded during December 1939 and January 1940. Secular variations are the differences between these values and those published for January 1, 1939 (see Geophys. Abstracts 97, No. 4902). 
The table contains (1) absolute values for the epoch 1940.0, and (2) secular variations for the elements of declination; of inclination; of horizontal, vertical, north, and west components; and of the total force.$W . A$.

Fischer, J. W., An experimental device for computing magnetic and gravitational anomalies. See Geophys. Abstract 5456.

5468. Hallimond, A. F., Magnetic observations on the Brockhill dyke: Geol. Survey of Great Britain Bull., No. 2, pp. 85-92, London, 1939.

The course of the dyke as indicated by magnetic mapping is shown in a figure. At the east end the dyke thins to a foot or so and then disappears altogether. At the west end the last evidence shows the dyke under about 30 feet of cover beneath an alluvial flat, but there is no sign that it extends westwards beneath the road. No outcrop of the dyke has been found either in the east or west banks of the river Teme beyond these points. Thus the proved course is about three-fourths mile. The thickness indicated by the magnetic profiles nowhere exceeds 30 feet, and part of this may be due to the margins of altered country rock. Apparently the dyke is confined to the floor of the Teme Valley.-Author's summary.

5469. Hallimond, A. F., and Whetton, J. T., Magnetic survey of haematite ore in south Cumberland and Furness: Geol. Survey of Great Britain Bull., No. 2, pp. 1-17, London, 1939.

The present work has fully confirmed previous observation that the Cumberland haematite is appreciably magnetic. Under 60 feet of cover it should be possible to detect the outcrop of a vein 15 feet wide. Very special caution is necessary in applying magnetic methods to this type of ore. (1) The values observed are much smaller than those due to most dyke rocks. In the past, many surveys have been made with an accuracy of reading of \pm 3 gamma but with errors due to use of a distant base of the order of 10 gamma. Such accuracy would be practically useless for the present purpose. With the precautions here indicated a comprehensive accuracy of \pm 2 gamma, or even \pm 1 in shorter traverses, can be attained. It is only under these special conditions that magnetic prospecting for haematite should be undertaken. (2) The anomaly, being small, is comparable with those due to buried objects such as large boulders in boulder clay, or to magnetic country rocks. In every case such possibilities must be borne in mind; not only the size but the distinctive form of the anomaly must be shown to correspond with that to be expected for the ore body whose presence is deduced. It would be quite inadmissible to bore on every "high" on the assumption that an ore body will be present.

The local results may be summarized as follows: Trials with a vertical magnetic field balance were made over an elongated body of haematite ore, known to have a cross section of about 50 feet, a depth of 100 feet, and a cover of about 60 feet of boulder clay, situated near Red Hill Farm, Millom, Cumberland. An anomaly of about 30 gamma was observed. Using precise methods, a detailed magnetic survey was then made of a neighboring area about 1,000 feet square. A parallel elongated anomaly was located, similar to that found in the first trials, and this is associated with an ore body, which, so far as it has been explored, is closely comparable with its previously known neighbor.-Authors' conclusions and summary. 
5470. Jackson, W. E. W., Agincourt magnetic data, 1899-1937, and the sunspot cycle: Royal Astron. Soc. Canada, Jour., vol. 33, No. 12, pp. 401-414, Toronto, December 1939.

Photographic records of the variations in declination, $D$, and horizontal force, $F$, have been obtained at the Agincourt Magnetic Observatory over three sunspot cycles, and of vertical force, $V$, over two. Tables of the mean monthly and annual values of $D, H$, and $V$, as well as tables of mean monthly diurnal ranges of these quantities, are given. It is shown by a Jeast-squares calculation that $D, H$, and $V$ can all be expressed as linear functions of the Wolfer sunspot number. It is concluded that there is some force at work in the sun which manifests itself in two distinctly different phenomena: sunspots on the one hand, and variations in the earth's magnetic field in the other.-G. C. McV., Sci. Abstracts, vol. 43, No. 50\%, 1940.

5471. Jarman, C. A., Rayner, J. M., and Nye, P. B., Geophysical report on the Iron Range area, Claudie River gold and mineral field, Portland Roads district: Aerial, Geol., and Geophys. Survey of Northern Australia, Rept. 13, 7 pp., Canberra, 1937.

The Iron Range area is a part of the Claudie River gold and mineral field, Cape York Peninsula. As the problem was to trace magnetic material (slates more or less replaced by hematite and magnetite), the only method used was the magnetic. The instruments employed were a Watts vertical magnetic balance and a Thalen-Tiberg magnetometer. The results of the magnetic survey are presented on a plan of the Iron Range area, showing geology and contours of the vertical component of the magnetic field, with insets showing selected magnetic profiles and a section and magnetic profile along and above Gordon's adit. Although the survey has yielded information regarding geologic structure, such information is not so specific and detailed as was expected. The anomalies that were obtained indicated many bodies of iron slate throughout the area; they did not, however, indicate long, narrow, and continuous bands of iron slate, but rather short and discontinuous bands. The detailed structure, including the detection of faults and folds, therefore could not be obtained. $-W$. $A$.

5472. Jenny, W. P., Some practical examples of micromagnetic prospecting: Oil and Gas Jour., vol. 38, No. 50, pp. 132-134, Tulsa, Okla., 1940.

To distinguish between the old magnetic method, which deals essentially with basement igneous rocks, and its newer development into a highly accurate and refined method that predicts structures. within the sedimentary column, the term "micromagnetics" has been introduced. Practical examples, accompanied by maps that show micromagnetic isogams, are discussed to prove that the micromagnetic method has been developed into a very useful tool for the geologist.-W. $A$.

5473. Jones, W. M., Magnetic observations of Nelson serpentinites, with remark on the geology of the asbestos deposits: New Zealand Jour. Sci. Technology, vol. 21, No. 3b, pp. 128b-142b, Wellington, 1939.

The asbestos-bearing serpentinites of Upper Takaka show striking magnetic properties, variations of as much as 20,000 gammas in vertical intensity and of $176^{\circ}$ in declination having been detected. Those at Black Beach, D'Urville Island, showed a range of variation of about 10,000 gammas in vertical intensity, but the small outcrop near Bird's Hill, Takaka, gave much smaller effects, with a range of less than 1,000 gammas. 
The development of chrysotile asbestos in the serpentinites is associated in part with contacts of the latter with sedimentary rocks and gabbro intrusives, and possibly also with the proximity of acidic intrusives. The magnetic mapping shows up some of these contacts very sharply and can thus supply useful information for the prospecting and mining programme.-Author's abstract.

5474. Jordan, W. H., and Rothrock, E. P., A magnetic survey of south-central South Dakota: South Dakota State Geol. Survey, Rept. of investigations, No. 33, 19 pp., South Dakota Univ., Vermilion, 1940.

This survey has outlined a part of the divide between two basins: A large southeastern basin in Iowa and Nebraska and a northwestern basin in South Dakota. With information from this survey it is possible for an oil operator to select the regions where he wishes to prospect further with such instruments as the seismograph, gravimeter, and resistivity meter.

The article contains information on the theory of magnetic surveys, on instruments used, and on procedure. The anomalies encountered in this survey are fairly large, as the total relief is nearly 1,500 gammas. A magnetic map shows lines of equal vertical intensity.

Concerning geologic interpretation of the region investigated, the authors write: "Though it is always unwise to draw geological conclusions dogmatically from magnetic data, especially in regions where so little is known of the subsurface stratigraphy, the data obtained on this survey are sufficiently clear to warrant the following deductions: (1) The pre-Cambrian ridge between Sioux Falls and Mitchell extends westward at least as far as Chamberlain; (2) the pre-Cambrian surface slopes rapidly from this axis into basins north and south of the ridge, allowing the overlap of post-Cambrian strata from at least the late Paleozoic through the Cretaceous systems; (3) the surface of the pre-Cambrian is not a smooth plain but contains elevations and depressions which could be reflected as structures in the overlying rock." $-W . A$.

5475. Labrouste, M. and Mme. Henri, Étude statistique du cycle undécennal de la composante semi-diurne de la déclinaison magnétique [Statistical study of the 11-year cycle of the semidiurnal component of magnetic declination]: Acad. sci. Paris Comptes rendus, vol. 209, No. 19, pp. 689-691, 1939.

The semidiurnal component of magnetic declination has been analyzed in the same way as for the diurnal component (see Geophys. Abstracts 100 , No. 5325). The mean values of the semidiurnal amplitude can be classified according to geomagnetic latitude to $50^{\circ}$, but for higher latitudes the mean values are feebler. The magnetic curves of the 11-year semidiurnal amplitude are generally in phase with solar activity but with a retardation, notably for American stations. The 11-year-phase oscillation is sensibly in agreement with that for solar activity and shows a slight retardation for most stations, but not for Sodankyla or Lerwick.R. S. R., Sci. Abstracts, vol. 43, No. 505, 1940.

5476. Larroque, Jean, Observations magnétiques en A. O. F. [Magnetic observations in French West Africa]: Acad. sci. Paris Comptes rendus, vol. 210, No. 6, pp. 221-222, 1940.

The results of magnetic observations that were made during the past 3 years with Chasselon's apparatus are shown in a table. Reductions for diurnal and secular variations were not made.-W. $A$. 
5477. Lazareff, P. P., Methods of interpretation of magnetic observations applied in the region of the Kursk magnetic anomaly from 1918 to 1927 [in Russian]: Acad. sci. U. R. S. S. Bull., sér. géog. et géophys., No. 3, pp. 235-246, Moscow, 1939.

In part 1 the author discloses the methods used by the Commission of the Academy of Sciences of the Union of Soviet Socialists Republics in deciding whether the Kursk anomaly is caused by an underground electric current or by iron-bearing deposits. He derives formulas by which he explains the question and by which he shows, from data of the magnetic survey, that the Kursk anomaly is caused by ore deposits. In part 2 he discusses the methods that were applied by E. Leyst and himself for determining the depth of the deposit. These methods are based on the study of $Z, H$, and $D$ around the axial line of the anomaly. He concludes with a discussion of a method, based on measurements of $Z$ at different distances at the surface of the ground, for studying the depth of the deposits. The method gives for the maximum magnetization at Schtchigry a depth between 150 and $250 \mathrm{~m}$. According to drilling records, this depth was $150 \mathrm{~m}$.-Author's abstract, translated. by W. A.

5478. MeNish, A. G., and Johnson, E. A., Magnetization of unmetamorphosed varves and marine sediments: Terres. Magn. and Atmos. Electr., vol. 43, No. 4, pp. 401-407, Baltimore, Md., 1938.

Pertinent to the problem of the past history and character of the earth's magnetic field, the authors describe magnetic measurements on unmetamorphosed clay deposits of recent geological origin (Pleistocene clays) from New England and on deep-ocean bottom cores. The clay samples were carefully prepared and accurately dated geologically and chronologically, varying from the year 211 to 411 .

All varves exhibited magnetic polarization, consistently different from the present magnetic declination, suggesting a change in direction of magnetization of over $20^{\circ}$ from about the year 265 to the year 400 .

The experiments reported are of extreme interest in the problem stated and should be of import to workers in the field of exploration magnetics.-DD. W., Annot. Bibl. Econ. Geology, vol. 11, No. 2, 1989.

5479. Neumann, G., Regionale magnetische Variometermessungen in Südwestdeutschland 1932 [Regional magnetic-variometer measurements in southwestern Germany, 1932]: Beitr. angew. Geophysik, vol. 8, No. 1, pp. 18-44, Leipzig, 1939.

Regional measurements with the Schmidt field balance, manufactured by Askania, were made in 1932 in southwestern Germany for a preliminary investigation of possible oil deposits. The results showed great conformity with the investigations made previously by Haussmann. Three zones of magnetic disturbances could be clearly determined within the investigated area: A zone of higher intensities in the northern part of Württemberg, a large minimum in the central part of Württemberg, and rather high-intensity disturbances in some places in the southern part of Württemberg. The character of the magnetic disturbance in the upper Rhine-Graben is discussed. Very close relations are observed: 'between gravitational anomalies, especially of the Rhine-Graben and of north Württemberg. The relation between the regional geology and magnetic disturbances is examined. A clear interdependence could be established between the palaeographic borders of the old "vindelizisch Festland" and the magnetic anomalies in the central part of Württemberg.-Author's abstract, translated by W. A. 
5480. Rayner, J. M., Geophysical survey at Pinnacles mine, Broken Hill: Chem. Eng. and Min. Rev., vol. 32, No. 375, pp. 111-112, Melbourne, December 1939.

The magnetic method was especially applicable to the investigation of the geologic structure of the Pinnacles area, 10 miles northwest of Broken Hill. Marked magnetic effects arise from the amphibolites and from the quartz magnetite and small effects from the actual ore horizon. The most significant features in the search for ore, as indicated by this survey, are the anticlinal structure just north of the Pinnacles mines and the feature suggestive of buckling north of Pine Creek.

A full report of the survey is given in the "Annual report of the New South Wales Department of Mines for 1938."-W. A.

5481. Rayner, J. M., and Nye, P. B., The Silver Ridge auriferous lodes, Cloncurry district: Aerial, Geol., and Geophys. Survey of Northern Australia, Rept. 11, pp. 13-16, Canberra, 1936.

After a geologic examination and sampling, a brief, 3-day geophysical survey was made at Silver Ridge. Self-potential, electromagnetic, and magnetic methods were used; results are shown in the form of plans and graphs. The self-potential method gave reliable results so that the negative centers could be readily correlated with known lode outcrops. The magnetic method gave four anomalies, the cause of which, though rather obscure, may be due to secondary oxides of iron associated with some quartz veins. The anomalies appear, however, to have no. very specific association with the lode outcrop in general. The electromagnetic indications were so weak that they were not apparent in field readings. The indications that were obtained by the afore-mentioned methods do not suggest the presence of a large and extensive ore body.$W . A$.

Reich, Hermann, Closs, H., and Schoene, Hans-Joachim, On magnetic and gravimetrical investigations in the Kaiserstuhl. See Geophys. Abstract 5460 .

5482. Richardson, L. A., Rayner, J. M., and Nye, P. B., Magnetic prospecting at Tennant Creek: Aerial, Geol., and Geophys. Survey of Northern Australia, Rept. 23, Northern Territory, 11 pp., Canberra, 1937.

This is the second report dealing with magnetic prospecting at Tennant Creek (see Geophys. Abstracts 89, No. 3690). The problem discussed in this article consisted in detecting nonoutcropping bodies of iron oxides within such rocks as slates, schists, granite, related rocks, and acid volcanic rocks. The results of the survey are shown in the form of magnetic contour maps and of typical profiles. The surveys revealed 24 magnetic anomalies of deep-seated origin. . Details of major anomalies are given in a table.-W. $A$.

5483. Smertenko, L., The Khramy magnetic anomaly [in Ukrainian]: Jour. Geology, vol. 6, No. 3, pp. 99-102, Kiev, 1939.

A brief description of the Khramy magnetic anomaly is given, and existing hypotheses on the causes of negative magnetic anomalies are discussed. The hypothesis is advanced that the Khramy negative magnetic anomaly is the result of lightning discharges on basaltic rocks, which possess a high residual magnetization. The results of checking this hypothesis are given. The existence of high residual magnetization in the basalts, with different directions of the vector of this magnetiza- 
tion, was established. The existence of rocks fused by lightning (fulgurites) confirms the author's hypothesis.-Author's abstract, translated by $W . A$.

5484. Strona, A. A., Magnetic anomalies in the regions of Krivoy Rog and Krementchug [in Russian]: Sovetskaia Geologiia, vol. 9, No. 10-11, pp. 78-93, Moscow, 1939.

The author describes the geologic results of a detailed magnetic survey that was made from 1923 to 1932 over an area of about $2,000 \mathrm{~km} .^{2}$ The area, which is about $230 \mathrm{~km}$. long and 4 to $35 \mathrm{~km}$. wide and which is shown on a map, forms a strip that extends between longitudes $33^{\circ} 10^{\prime} \mathrm{E}$. and $34^{\circ} 05^{\prime} \mathrm{E}$., and between latitudes $47^{\circ} 39^{\prime} \mathrm{N}$. and $49^{\circ} 30^{\prime} \mathrm{N}$. Values of declination, vertical components, and horizontal components were determined by Tiberg-Thalen magnetometers at 190,000 stations.

The geologic structure of many places hitherto unknown to geologists was established. Strong magnetic anomalies were found in the regions of Krivoy Rog, Pridneprovsk, and Krementchug. The greatest success of the magnetic survey was in determining large iron-ore deposits near Krementchug. A series of about 30 areas of weak yet interesting magnetic anomalies was established in the region of the Jeltaia and Zelenaia Rivers, in the upper parts of the Inguletz River, and along the right bank of the Dnieper. Some of these areas are considered to be of commercial value. $-W . A$.

5485. Wolff, Wilnelm, Magnetische Untersuchungen über einem Basaltvorkommen am Salzstock von Rolfsbüttel [Magnetic investigations over a basalt intrusion at the Rolfsbüttel salt dome]: Beitr. angew. Geophysik, vol. 8, No. 1, pp. 78-84, Leipzig, 1939.

Magnetic $Z$-measurements carried out by means of an Askania magnetometer at the western edge of the Rolfsbüttel salt dome are described. Two wells drilled for potash near the area under investigation struck weathered basaltic rocks attributed to a possible small dike crossing the salt dome. Positive anomaly of vertical intensity was found a short distance to the east of the edge of the dome. The elongated shape of the anomaly and its position between the two wells seems to prove that the existence of the basalt dike is the cause of the magnetic anomaly, the latter amounting to maximum $30 \gamma$. Tectonic relations between the basalt intrusion and the salt-dome structure appear to be possible. Positive anomalies of minor importance (up to $15 \gamma$ ) may be attributed to differences in susceptibility within the sedimentary formations. It seems that at some places the salt dome produces a weak negative disturbance if compared with that of the surrounding formations.Author's abstract.

\section{SEISMIC METHODS}

5486. Beers, R. F., Velocity stratification as an aid to correlation: Geophysics, vol. 5, No. 1, pp. 15-21, Menasha, Wis., 1940.

This paper outlines the historical development of the concept "velocity stratification" from the field data of refraction and reflection seismographs. The concept is shown to form the basis of the phenomenon known as "seismic reflections." Experimental data are interpreted to show approximately the magnitude of reflection coefficients. Employment of velocity stratification as a means of stratigraphic correlation is suggested. Means whereby data for these correlations may be 
collected are discussed. Finally the use of the method for attack on stratigraphic problems is outlined.-Author's abstract.

5487. Bignell, L. G. E., Sound waves used to take potential: Oil and Gas Jour., vol. 37, N'o. 16, pp. 49-50, Tulsa, Okla., 1938.

A method is described for determining the static fluid level in a well, and the drop in fluid level after a period of pumping. This procedure is used in determining potentials and in finding accurately static fluid levels. One advantage of the process is that no special equipment for the well itself is required: A casing-head unit containing a microphone, a special chamber for exploding a cartridge to create a sound wave, and: a special vacuum-pulse amplifier for direct recording by stylus on moving. paper of the return wave sent back from each tubing collar, liner top, tubing catcher, or the fluid surface itself. These points in a cased well give off characteristic echoes as recorded, and the method permits an accurate logging of them. The sound wave sent down travels in the angular space between tubing and casing. A gauge on the casing-head unit attached for the work shows gas pressure.-D. W., Annot. Bibl. Econ. Geology, vol. 11, No. 2, 1939.

5488. Bullen, K. E., On Rayleigh waves across the Pacific Ocean: Royal Astron. Soc. Monthly Notices, Geophys. Suppl., vol. 4, No. 8, pp. 579-582, London, 1939.

An analysis has been made of the dispersion of Rayleigh waves recorded at Wellington from the Bering Sea earthquake of November 10, 1938. Using dispersion curves of Jeffreys based on a hypothetical structure corresponding to an upper layer of granite resting on a mantle of olivine, the indicated crustal thickness for the Pacific region involved was about $18 \mathrm{~km}$., as compared with a thickness 8 to $10 \mathrm{~km}$. greater found by Jeffreys for Eurasia on the same hypothesis. This difference of thickness is in agreement with Stoneley's comparison of the two regions using Love waves. The use of dispersion curves of Sezawa, which would fit a somewhat denser crustal layer, would indicate a thickness of order $26 \mathrm{~km}$. for the Pacific region in question.-Author's summary.

5489. Bullen, K. E., Theoretical traveltimes of the phases $P P, P P P, P S, P P S$, $S S$, PSS, and SSS: Royal Astron. Soc. Monthly Notices, Geophys. Suppl., vol. 4, No. 8, pp. 583-593, London, 1939.

The recent improvements made by Jeffreys to the $P$ and $S$ traveltime tables (see Geophys. Abstracts 99, No. 5199) have resulted in tables that appear to be final so far as the average earthquake is concerned. In the present paper these tables are used to calculate theoretical traveltimes for phases that have undergone reflection at the earth's outer surface. The results are all based on the hypothesis that each reflection is a true surface reflection. The author used the method of matching gradients and took special care in dealing with the direct and refracted rays that were associated with sharp changes of $d T / d \Delta$ for component paths near $20^{\circ}$. He carried the first decimal figure in all computations and rounded off the results finally to the nearest second. Table I gives the traveltimes for a surface focus for all phases that were considered. Tables II-VIII contain depth allowances in seconds to be subtracted from the times of table I. Sufficient data have been given in all the tables to enable the rapid estimation of any particular traveltime within an error not exceeding about 1 sec.- $W . A$. 
5490. Byerly, Perry, Seismicity of the northern Pacific coast of the United States: Geol. Soc. America Bull., vol. 51, No. 2, pp. 255-260, Washington, D. 'C., 1940.

A map is presented showing the epicenters of strong earthquakes, the earlier ones being located from field data obtained from the "Descriptive catalog of earthquakes of the Pacific coast of the United States, 1769 to '1928'. (see Geophys. Abstracts 98, No. 5135), and the later from instrumental data. Some general conclusions are suggested from the distribution of these epicenters. The seismicity of groups of counties in northern California is rated on an arbitrary scale. "The seismicities are presented in the form of a map.-Author's abstract.

5491. Dix, C. H., Derivatives of traveltime curves: Seismol. Soc. America Bull., vol. 30, No. 1, pp. 25-26, Berkeley, Calif., 1940.

The author discusses mathematically the behavior of the second derivative, $d^{2} t / d \Delta^{2}$, when the source is at the surface, $r=r_{0}$, and $\Delta=r_{0} \theta$; where $\theta$ is the angular distance from the source to where the time $t$ is measured. He assumes that the velocity of propagation, $V(r)$, is a function of $r$ only. $-W$. A.

5492. Howell, L. G., Kean, C. H., and Thompson, R. R., Propagation of elastic waves in the earth: Geophysics, vol. 5, No. 1, pp. 1-14, Menasha, Wis., 1940.

An investigation of elastic-wave propagation in near-surface materials. using single-frequency continuous waves and pulses, over a range of 20 to 1400 cycles, is described. While only touching upon the diverse problems involved in a study of this kind, the results indicate a complexity requiring considerable research if a proper understanding, commensurate with the importance of the problem, is to be attained.Authors' abstract.

5493. Jeffreys, Harold, Times of transmission for small distances and focal depths: Royal Astron. Soc. Monthly Notices, Geophys. Suppl., vol. 4, No. 8, pp. 571-578, London, 1939.

Tables are given for (1) the times of transmission for a surface focus, and (2) the times of transmission at short epicentral distances for different focal depths. $-W$. $A$.

5494. Jeffreys, Harold, The times of the core waves, 2d paper: Royal Astron. Soc. Monthly Notices, Geophys. Suppl., vol. 4, No. 8, pp. 594-615, London, 1939.

Determinations of the times of $P K P$, with an additional branch running back to about $110^{\circ}$, of the times of $S K S$, and of the corresponding times of $K$ have already been given (see Geophys. Abstracts 99, No. 5201). A preliminary calculation of the times of other core waves showed that they fell into two main types: (1) Time-curves resembling the curve for $P K P$, and (2) those having other forms. A mathematical discussion and tables are given for the times of several core waves.-W. $A$.

5495. Kanai, Kiyoshi, Theory of the aseismic properties of the brace strut (sudikai) in a Japanese-style building, parts 2 and 3: Tokyo Imp. Univ., Earthquake Research Inst., Bull., vol. 17, No. 3, pp. 559-578, 1939.

In part 2 the author determines, by mathematical investigation, the dynamical theory of the aseismic properties of partial braces (hodue) and also such parts of the theory of the usual brace struts as were omitted in part 1 of this series (see Geophys. Abstracts 100, No. 5348). 
In part 3 he shows, from mathematical investigation, that the increase in the stiffness of brace struts that are fitted to a structure is invariably accompanied by increased natural frequency of the same structure as well as by decreased resonance amplitudes.

He concludes that the aseismic properties of brace struts are much more pronounced in diminishing resonance amplitudes than in raising natural frequencies of a structure; therefore he recommends the addition of brace struts to any structure for diminishing resonance amplitudes rather than for raising natural vibration frequencies.- $W . A$.

5496. Mitera, Z. A., Reflection-seismograph survey of the frontal area of the Boryslaw fold at Tustanowice [in Polish]: Kopalnictwo Naftowe, No. 12, pp. 365-371, Boryslaw, 1938.

The first successful seismic survey of the enigmatic area at the front of the Boryslaw fold has been carried out by means of a new reflection apparatus of American origin. It can now be taken for granted that the Boryslaw dome is not the last marginal fold of the Carpathian Flysch series but that there still emerges another frontal fold of sufficient extent to deserve a closer examination.-J. Z., Annot. Bibl. Econ. Geology, vol. 11, No. 2, 1989.

5497. Mitera, Z. A., and Wyrobek, St., A seismographic survey of the environs of Daszawa, south Poland, by Pioneer Co., Ltd. [in Polish]: Przemysl Naftowy, No. 4, pp. 95-99, Lwów, 1938.

A survey of the largest Polish gas field by the reflection seismograph is discussed. The results were not especially satisfactory in the soft Tortonian beds. The gently undulated structure is illustrated by five seismic cross sections.-J. Z., Annot. Bibl. Econ. Geology, vol. 11, No. 2, 1989.

5498. Perri, Emilio, Nuovo ascelerometro a massima per la componente orizzontale [The new horizontal-component maximum accelerometer]: Geofisica pura e applicata, vol. 1, No. 3/4, pp. 137-154, Messina, 1939.

A description is given of a new type of maximum accelerometer that is provided with an elastic pendulum and a variable scale. The apparatus, although of comparatively small weight, shows by its sensitiveness and functioning that it is of safe construction and is well adapted for direct determination of maximum seismic force.-Author's abstract, translated by $W . A$.

5499. Ramirez, J. E., An experimental investigation of the nature and origin of microseisms at St. Louis, Mo., part 1: Seismol. Soc. America Bull., vol. 30, No. 1, pp. 35-84, Berkeley, Calif., 1940.

Microseisms are natural, regular, ground oscillations that are produced neither by earthquakes nor by artificial means, such as dynamite explosions and traffic. The author cites some of the many names that are given in different countries to these phenomena because of their puzzling character. He gives a historical outline of investigations on microseisms. He restricts the present investigation to microseisms of the most common type, namely, those varying in period from 3 to 9 seconds Attention has been focused on the traveling nature of these waves and consequently on such problems as their direction of propagation, their speed, their amplitude and period variations, their wave length, the motion of a ground particle, and their origin. The author described the instruments that he used and adds 32 figures, 12 tables, and a list of references.-W. $A$. 
5500. Reich, Hermann, Laufzeitplan und Geologie in Ostpommern und im Alpenvorland [Traveltime plan and geology in eastern Pomerania and in the foreland of the Alps]: Oel und Kohle, vol. 35, No. 41, pp. 740-743, Berlin, 1939.

By examples from the two far-removed regions of Pomerania and the Alps, the author shows how the method of a traveltime plan, based on refraction observations, must be conducted to obtain all possible information offered by this method. The great distance between these two regions makes the influence of layers close to the surface disappear entirely or renders this influence insignificant. Under favorable conditions, various geologic sections may be understood and the relation between their layers made clear, independently of one another. The author emphasizes the need for a great amount of general work carried on by the Government, as sufficient results cannot be obtained if only private work is conducted on a small scale.-Author's abstract, translated by $W . A$.

5501. Riznichenko, G., On the theory of a seismic hodograph [in Russian]: Acad. sci. U. R. S. S. Bull., sér. géog. et géophys., No. 3, pp. 247-266, Moscow, 1939.

The differential equation is derived for the times of arrival of disturbances in a soiid medium. The solution is shown for given boundary conditions. The problem is generalized for a layered medium. The method is used to analyze some special problems of interest in seismic prospecting, in particular the interpretation of multi-layered structures.-Author's abstract, translated by W. A.

5502. Riznichenko, G., Vibrating inertia platform [in Russian]: Acad. sci. U. R. S. S. Bull., sér. géog. et géophys., No. 3, pp. 267-274, Moscow, 1939.

The vibrating inertia platform is intended for tests of oscillographs at small displacements. The principle of its operation is based on the following idea: There are two masses, $M_{1}$ and $M_{2}$, a force $F$ acting between them. If the system $M_{1}$ and $M_{2}$ is isolated, the displacements of masses relatively to the center of inertia of the system are inversely proportional to the masses.

The apparatus is designed as follows: The mass of the platform $M_{1}$ is suspended by means of an elastic suspension to a fixed point. A vibrator is mounted on the platform. Its mass $M_{2}$ is thrown into motion by means of an electromechanical transformer, which receives electric impulses (e. g. from a photogenerator). The frequency characteristic of the vibrator is of no principal importance. For the definition of small displacement $X_{1}$ of the platform there are measured the sufficiently great relative displacements $X_{2}$ of both masses $M_{1}$ and $M_{2}$. If the frequencies of oscillations are sufficiently high the motion approaches to the motion of an ideal isolated system, and then the motion of the mass $M_{1}$ is defined from the formula $X_{1}=\frac{M_{2}}{M_{1}+M_{2}} X_{2}$.

When the parameters are properly chosen, the errors of definition of the vibrating platform displacements by this formula do not surpass 1 percent for all the frequencies from $2 \mathrm{~Hz}$ and higher.-Author's English abstract. 
5503. Rosini, E., New type of wave of longitudinal character between the phases $P$ and $S$ : Ricerca sci., vol. 10, pp. 798-808, Rome, September 1939.

Even in the interval of the epicentral distances in which the seismograms have the most simple interpretation there is frequently observed the presence of trains of waves not yet defined. The present paper treats of the individualization of a type of wave, situated between the $P$ and the $S$, that seems to present some well-defined characteristics peculiar to itself. The research so far is entirely of an observational nature and includes the construction of a provisional dromochrome of the new wave. In the present description of its chief characteristics this wave has perfect longitudinality and period relatively long increasing with the distance.-J. J. S., Sci. Abstracts, vol. 43, No. 505, 1940.

5504. Sezawa, Katsutada, and Kanai, Kiyoshi, Formation of boundary waves at, the surface of a discontinuity within the earth's crust, part 2: Tokyo Imp. Univ., Earthquake Research Inst., Bull., vol. 17, No. 3, pp. 539-547, 1939.

In their previous paper (see Geophys. Abstracts 96, No: 4819) the: authors showed how body waves generated from a point source in a. solid excite boundary waves of the Stoneley type at any discontinuous: surface in the same solid. The condition they discussed in that paper involved two dimensions only. In this paper they give a mathematical discussion for a three-dimensional condition.- $W$. $A$.

5505. Sezawa, Katsutada, and Kanai, Kiyoshi, Microseisms caused by transmission of atmospheric disturbances, part 2: Tokyo Imp. Univ., Earthquake Research Inst., Bull., vol. 17, No. 3, pp. 548-558, 1939.

In part 1 of this article (see Geophys. Abstracts 100, No. 5363) the authors ascertained that prevalent periods of vibration in microseisms could result from the stratification in the path of transmission of the disturbance. In the present paper the authors discuss mathematically the condition of an atmospheric disturbance as it is being transmitted through a layer, outside of or within which a steady air current is blowing. When it is possible for the disturbance to be transmitted through such a layer, the amplitude of the waves: becomes maximum for a certain range of periods, a condition that would be one of the chief causes of microseismic oscillation.

The present investigation indicates only a theoretically possible: atmospheric condition, which may be confirmed after careful observations have been made.-W. $A$.

5506. Specht, Zdzislaw, Problem of inclined layers in seismic-reflection methods: Am. Inst. Min. Met. Eng., Tech. Pub., No. 1177, 7 pp., New York, 1940.

This paper discusses elementary laws pertaining to seismic-reflection: methods and presents a general but simple criterion for determining the: direction of dip of a reflection horizon from observational data of distance and time.-W. $A$.

5507. Terada, K., "Tunami" or destructive sea waves excited by a traveling: cyclone: Imp. Marine Observatory Mem., vol. 7, No. 2, pp. 209-230, Kobe, July 1939.

Mathematical expressions are developed for the general theory of "tunami" and applied to three special cases for a rectangular lake:

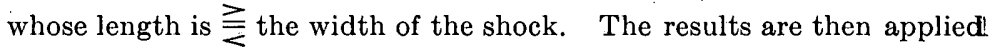
$286071-41-3$ 
to provide a partial explanation of the "tunami" at Oosaki and its surroundings during the typhoon of September 21,1934 . It is concluded that (1) the elevation is a maximum when the velocity of the typhoon coincides with the value $\sqrt{g h}$, where $h$ is the depth of the lake; (2) the time lag of occurrence of maximum elevation after the arrival of the typhoon center generally increases as the velocity of the typhoon increases; and (3) when a typhoon crosses a bay, the maximum elevation at the place where the typhoon ceases to cross the bay is generally greater than at the place where it begins to cross the bay. $-R$. $S . R$, Sci. Abstracts, vol. 43, No. 507, 1940.

5508. Toperczer, Max., Theoretical treatment of earthquakes: Akad. Wiss. Wien, Ber., vol. 148, 2a, No. 1-2, pp. 1-32, 1939.

The results obtained by earlier writers on the mathematical treatment of the initial phase are reviewed. The conditions used are specified, and a disturbance function for the motion is obtained. The equation for the pendulum motion is next derived and with the help of these formulas the complete solution of a special case of surface movement is obtained. Difficulties of a mathematical nature do not occur in spite of the complicated assumptions made, but numerically there are difficulties in the solution of the equation. After a general discussion of the solution, the initial magnification obtained and the phase displacement of the pendulum are examined and the results compared with other solutions.-R. S. R., Sci. Abstracts, vol. 49, No. 507, 1940.

5509. von Thyssen-Bornemisza, Stephan, Die Temperaturabhängigkeit elastischer Eigenschaften von Zechsteinsalz [Dependence of elastic properties of Zechstein salt on temperature]: Oel und Kohle, vol. 35, No. 45, p. 767, Berlin, 1939.

The possibility of measuring the influence of temperature on the elasticity of rocks has already been indicated by the author (see Geophys. Abstracts 96, No. 4823). The description of a new device for measuring traveltimes was given in another article (see Geophys. Abstracts 98, No. 5068). Later, an additional arrangement to this device made possible the heating of cylindrical samples of rocks from $20^{\circ}$ to $320^{\circ}$, so that a series of cores of different materials could be investigated.

In this article the author describes the results of his investigation of a sample of Zechstein salt taken from a depth of $400 \mathrm{~m}$. The influence of temperature on the traveltimes of elastic waves in Zechstein "for temperatures increasing from $20^{\circ}$ to $320^{\circ}$ and decreasing from $320^{\circ}$ to $20^{\circ}$ are shown in two diagrams. The diagrams agree well with each other.-W. A.

5510. Weatherby, B. B., History and development of seismic prospecting: Oil Weekly, vol. 97, No. 5, pp. 67-69, Houston, Tex., 1940.

The paper reviews the development of the refraction and reflection methods of seismic prospecting. The refraction method has a historical background extending back to experiments in 1850 by the Irish physicist, Robert Mallet, but the method was not reduced to commercial practice until 1923 by a German company, the Seismos Gesellschaft. The reflection method dates back only to 1917 and was reduced to commercial practice by the Geophysical Research Corporation in 1927. The entire credit for the development of the seismic-reflection method belongs to American experimenters and companies. The total cost of 
seismic exploration in this country has been somewhat less than $\$ 200$,000,000 , and the work has resulted in the discovery of at least 4,000 ,000,000 barrels of oil.-Author's abstract in Oil and Gas Jour., vol. 38, No. 48, 1940.

5511. Wyszynski, O. W., Carpathian foreland in the environs of Kosow [in Polish]: Przemysl Naftowy, No. 5, pp. 113-119, Lw6w, 1938.

A gentle dome in the Miocene strata of the Carpathian foreland close to the Rumanian boundary is reported. This dome has been discovered by the "Pioneer" Co. after a thorough exploration by means of the reflection seismograph and the drilling of a number of shallow wells. It contains a productive gas horizon at a depth of $154 \mathrm{~m}$., or 505 feet. A deep well since drilled penetrated the Miocene series and reached the Cretaceous basement at 1,423 m., or 4,668 feet.-J. Z., Annot. Bibl. Econ. Geology, vol. 11, No. 2, 1939.

\section{ELECTRICAL METHODS}

5512. Fritsch, Volker, Influenza delle condizioni geoelettrici sulla caduta del fulmine [Influence of geoelectric conditions at lightning discharges]: Geofisica pura e applicata, vol. 1, No. 3/4, pp. 175-216, Messina, 1939.

Geologic conductors are affected in the same way by both lightning discharges and high-frequency alternating currents. Estimates of the conduction of lightning discharges in the ground can be made on the basis of facts known in radio geology. The geoelectrical effect of lightning is theoretically clear and is proved by many observations. The question of the existence of the so-called "lightning nests" must be answered positively. Statistical data obtained so far are often not satisfactory; uniform and satisfactory data must therefore be collected. - Establishment of special experimental lightning fields would be of great advantage in further investigations.-Author's abstract, translated by W. A.

5513. Kelly, S. F., Geophysics in molybdenite discovery: Mining Jour., vol. 23, No. 22, p. 7, Phoenix, Ariz., 1940.

An electrical survey was made near the open pit of the old Spain mine, near Renfrew, Ontario, to see whether hidden deposits of molybdenum ore could be discovered. Strong electrical currents were discovered in an area about 200 feet"east of the old workings. The deposit of molybdenum ore in this zone was proved by drilling. $-W$. $A$.

5514. Leavenworth, P. B., A comparison between electrical well logging and core analysis [abstract only]: Oil and Gas Jour., vol. 38, No. 47, p. 56, Tulsa, Okla:, 1940.

The comparison between electrical well logging and core analysis is discussed as applied to the problems of correlation, well completion, estimates of recoverable oil, and well spacing in the Gulf coast area. Selfpotential curves ("porosity" curves) may generally be correlated without difficulty, except that in the Miocene there is no known normal section which can be utilized regionally. Fault inspections are hard to determine in this series because of the absence of markers. Resistivity curves serve to indicate the nature of the fluid occupying a bed. Definite increases in the resistivity curve opposite increases in the self-potential curve distinguish oil and gas shows. Variations and distortions of this picture present many perplexing problems. Gen- 
erally, electrical logs are satisfactory for correlation purposes, but for problems arising within the reservoir itself core analysis gives much valuable supplementary information.-Author's abstract.

5515. Pekeris, C. L., Direct method of interpretation in resistivity prospecting: Geophysics, vol. 5, No. 1, pp. 31-42, Menasha, Wis., 1940.

A method is given of determining the variation of conductivity with depth for the case of a horizontally layered earth.-Author's abstract.

5516. Rayner, J. M., and Nye, P. B., Geophysical report on the Dobbyn area, Cloncurry district: Aerial, Geol., and Geophys. Șurvey of Northern Australia, Rept.. 4,-12 pp., Canberra, 1936.

The small township of Dobbyn is about 88 miles northwest of Cloncurry, in the northwestern part of Queensland. A geophysical survey of the Dobbyn area was made with the object of determining any extensions of known copper ore bodies and of locating hitherto undiscovered bodies. The electromànetic method with compensator was used mostly, but the Racom, magnetic, and self-potential methods also were employed to supplement it. Definite results as regards the location of hitherto undiscovered ore bodies were not obtained by the geophysical survey, but possible extensions of known ore bodies were indicated. Seven plates containing many maps, profiles, and contour lines show the final results of the survey.-W. $A$.

5517. Rayner, J. M., and Nye, P. B., Geophysical report on the Soldiers Cap area, Cloncurry district: Aerial, Geol., and Geophys. Survey of Northern Australia, Rept. 4, 15 pp., Canberra, 1936.

Soldiers Cap is about 30 miles southeast of Cloncurry. Although gold has been won from several small mines in the Soldiers Cap area, the Mount Freda body appeared to offer the only possibility of developing a considerable tonnage of ore. The preliminary aim of the geophysical survey, therefore, was an attempt to elucidate the structure of the area surrounding Mount Freda. Several geophysical methods were used. The instrumental equipment comprised: (1) The Racom, which measures the ratios of potential drops between successive equidistant points on a traverse; (2) the electromagnetic compensator, which measures the absolute intensity of the electromagnetic field; (3) the magnetic vertical balance, which measures the vertical intensity of the magnetic field of the earth; and (4) the self-potential meter with amplifier.

The electromagnetic method was the principal one used. It proved that the reef was associated with a highly conductive zone that was interpreted as being a shear zone.

Results of the surveys are graphically represented in four plates.W. A.

5518. Rayner, J. M., and Nye, P. B., Geophysical report on the Trekelano area, Cloncurry district:' Aerial, Geol., and Geophys. Survey of Northern Australia, Rept. 5, 18 pp., Canberra, 1936.

A geophysical survey was made in the vicinity of the sulfide ore exposed in the Trekelano mine, which is 10 miles southeast of Duchess and about 80 miles southwest of Cloncurry, in the northwestern part of Queensland. A geological survey was made concurrently with the geophysical survey. The geophysical survey depended primarily on electromagnetic methods of prospecting. Although the Turam method was used to a slight extent, the greater part of the survey was carried 
out with the compensator equipment. Other methods-the Racom, self-potential, and magnetic-were used to supplement. the Turam method. Final results of the geophysical survey are shown by many maps and profiles.

In summary, the electromagnetic methods and potential gradients show the ore body to be a good conductor (which agrees with resistivity measurements taken in the mine and open cut); the self-potential method shows a negative center (which agrees with theoretical considerations); and the magnetic profile shows a magnetic "high" not far from the lode. $-W$. $A$.

5519. Rayner, J. M., and Nye, P. B., Geophysical report on the Mount Todd auriferous area, Pine Creek district: Aerial, Geol., and Geophys. Survey of Northern Australia, Rept. 6, 7 pp., Canberra, 1937.

The area surveyed and described in this report is about $13 / 2$ miles west of Mount Todd. The area contains two prominent reefs known as the Jones Bros. reef and the Tollis reef, which are auriferous. A reconnaissance survey demonstrated that in this area reefs of the quartz-ironstone type can be located by the potential-ratio method under all conditions except where large thicknesses of alluvial overburden exist. Most of the survey was made on the Jones Bros. reef, where several poorconductor indications were obtained. The most pronounced indication was obtained in the central part of the reef in a zone of high resistivity that was due probably to silification. As a result of the geophysical survey of the Jones Bros. reef, several sites for testing have been recommended. As the two tràverses of the Tollis reef represent no more than test traverses, results of economic importance are not to be expected. A map shows details of the indications obtained from the survey, which was made by the potential-ratio method.- $W$. $A$.

5520. Rayner, J. M., and Nye, P. B., Geophysical report on the Dugald River silver-lead lodes: Aerial, Geol., and Geophys. Survey of Northern Australia, Rept. 7, 15 pp., Canberra, 1937.

The Dugald River silver-lead lodes are on the west side of the Dugald River, 40 miles northwest of Cloncurry. The geology of the part of the area that was geophysically surveyed is shown on a plate. The area surveyed was about 6,000 feet long and about 2,000 feet wide. Although several methods were tried, the self-potential and the electromagnetic methods were mainly used because they gave best results in the survey of the first traverses. Clear indications were obtained with both methods.

Results of the survey are shown on the following three plates: (1) Geophysical layout showing indications and geology; (2) Contour maps: (a) Real horizontal component of the electromagnetic field, (b) Selfpotential results, and (c) Vertical component of the magnetic field; and (3) Selected geophysical profiles and corresponding geologic sections. $-W . A$.

5521. Rayner, J. M., and Nye, P. B., The Woolwonga area, Pine Creek district: Aerial, Geol., and Geophys. Survey of Northern Australia, Rept. 11, Northern Territory, pp. 17-22, Canberra, 1937.

The Woolwonga area includes most of the Woolwonga gold field and the principal workings therein. It comprises a few low hills that contain reefs and reef workings. The hills consist of pre-Cambrian slates and sandstones. The geophysical survey was made in order to trace 
any extensions of known reefs or to detect hitherto unknown reefs under the alluvium. The potential-ratio (or Racom) method was the only one used because it was considered the most suitable method for detecting narrow quartz reefs, which are poor electrical conductors. Many anomalies that correspond to poor conductors were observed. A contour map shows the anomalous area. Indications obtained agree fairly closely with the strikes of the known quartz reefs. $-W . A$.

5522. Reistle, C. E., Jr., and Sikes, S. T., Jr., Well depth measurements: 'Oil Weekly, vol. 90, No. 1, pp. 41-42, 44-45, 48; No. 2, pp. 40-42, 44-46, 49 ; No. 3, pp. 50, 52, 54, 58, 59, Houston, Tex., 1938.

The authors discuss the three fundamental problems involved in well depth measurements, namely: (1) The selection of some standard method of measuring vertical distances in a well; (2) the most accurate method of measuring length of tubular goods placed in wells, and correlation of such measurements with depth measurements; and (3) the correlation and accuracy of various special measuring devices employed in depth measurements.

The investigations here reported are part 1 of a series of three articles which were given as a paper at a meeting of the A. P. I. in May of 1938 at Wichita, Kans. The above matters are of interest in connection with electrical logging.-D. W., Annot. Bibl. Econ. Geology, vol. 11, No. 2, 1939.

5523. Thyer, R. F., Rayner, J. M., and Nye, P. B., Geophysical report on the Lolworth area, Charters Towers district: Aerial, Geol., and Geophys. Survey of Northern Australia, Rept. 24, 8 pp., Canberra, 1937.

The Lolworth area is north of the Cape River gold and mineral field. This area contains a number of small but rich gold deposits, chief of which are the Mons Meg and Midas ore bodies. The geophysical surveys were made in the vicinity of these two ore bodies. Three methods were employed-self-potential, electromagnetic, and potential ratio. The first two methods gave small anomalies that were not satisfactory enough for interpretation; the potential-ratio method gave results that appeared to be capable of interpretation and to be associated with the ore bodies. The results, which are described separately for the Mons Meg and Midas layouts, are shown on two plates: (1) Mons Meg layout, with plan showing contours of logarithm of potential gradients and profiles of potential ratio and potential gradient; also lease plan of Lolworth area; and (2) Midas layout, with plan showing contours of logarithm of potential gradients and profiles of potential ratio and potential gradient; also locality plan.-W. $A$.

5524. West, S. S., Three-layer resistivity curves for the Eltran electrode configuration: Geophysics, vol. 5, No. 1, pp. 43-46, Menasha, Wis., 1940.

A method is described by which standard curves of apparent resistivity vs. electrode separation can be calculated for certain electrode configurations from the published data for the Wenner configuration. Data are given for plotting curves representing 15 sets of values of the three-layer parameters in the case of the Eltran configuration.-Author's abstract.

5525. Wormell, T. W., Effects of thunderstorms and lightning discharges on the earth's electric field: Royal Soc. London Philos. Trans. A, vol. 238, No. 794, pp. 249-303, September 1939. 
The results of a series of observations of the potential gradient near the ground during thunderstorms are discussed. The recording instrument is intermediate in speed between the ordinary methods used for recording the potential gradient in fine weather and the high-speed oscillographs employed for detailed study of the variation of the field during short intervals of time. It yields a continuous record of the potential gradient and will also follow rapid changes up to a limit of less than 0.05 second. The observations extended over the years 1926-36 and were mostly made during the summer months. After general remarks regarding the observations and details relating to individual storms the electric field at the ground during a thunderstorm is discussed and interpreted according to the observed field changes. The relative frequency of various possible types of complex field changes and the variation with the magnitude and distance of the discharge are considered. In connection with the duration of the field changes the effects of multiple strokes in one channel are explained, and in complicated field changes the duration may be $>1$ second. A frequency of lightning flashes of 1 flash $/ \mathrm{km} .{ }^{2}$ per year is obtained. The recovery of the electric field after a lightning discharge is often exponential but is in many cases more complicated. The results are used to revise the estimates given by Wilson for some of the fundamental quantities in a thunder cloud. The objections raised by Simpson and Scrase to the Wilson mechanism of a thunderstorm are considered inadequate.-R. S. R., Sci. Abstracts, vol. 43, No. 506, 1940.

\section{RADIOACTIVE METHODS}

5526. Evans, R. D., and Alder, R. L., Improved counting-rate meter: Rev. Sci. Instruments, vol. 10, No. 11, pp. 332-336, Lancaster, Pa., 1939.

An improved counting-rate meter circuit is described whose output meter reads directly the average rate of appearance of pulses in a counter exposed to radioactive substances. Four output scales are provided on a 100-microampere meter, such that full scale corresponds to 7,200 , $2,200,1,450$, and 400 counts per minute. Even on the highest speed range, the output current is closely proportional to the counting rate over the entire scale. For very long counting rates, an optional register output is provided.-Authors' abstract.

5527. Evans, R. D., and Meagher, R. E., Direct-reading counting-rate ratio meter: Rev. Sci. Instruments, vol. 10, No. 11, pp. 339-344, Lancaster, Pa., 1939.

A multi-staged thermionic amplifier is described, using two discharge counters and having an output meter which reads directly the ratio of the activity of two radioactive sources. Continuous photographic recording of this ratio for two fractions of a rapidly decaying source, therefore, provides a direct observation of their relative activity which is invariant with time, even though a mixture of substances having a variety of half-periods is involved. The amplifier holds advantages of greater convenience and higher statistical accuracy over the usual single-counter amplifier when dealing with sources having moderate strength and half-periods near the range of 5 minutes to 1 hour. It is particularly suited to experiments in which such radioactive substances are used as chemical or biological indicators. A portion of the circuit, consisting of three thermionic tubes, has general applicability wherever direct observations are wanted of the ratio of two d. c. currents.Authors' abstract. 
5528. Imbò, Giuseppe, Radioactive sampling in Lake Ameno (isle of Ischia): Ricerca sci., vol. 10, No. 10, pp. 936-940, Rome, 1939.

By radioactive sampling, the spatial and temporal characteristics of - the line of earth fracture through Lake Ameno have been examined. The details of the origin of the thermal and radioactive phenomena are still unsettled.-F. C. C., Sci. Abstracts, vol. 48, No. 506, 1940.

5529. Rothé, Edmond, and Hée, Arlette, Sur une méthode d'étude de la radioactivité des roches [On a method of studying the radioactivity of rocks]: Acad. sci. Paris Comptes rendus, vol. 210, No. 1, pp. 30-32, January 1940.

A new method for studying the radioactivity of rocks is designated "method of the layers of variable thicknesses" (méthode des couches d'épaisseurs variables). Samples of rocks are investigated, and a curve shows the characteristic radioactive effect for each sample. The rocks are then classified according to the curves. A general idea of the content of radioactive elements of the thorium and uranium-radium families in various rocks is thus obtained. An application of the method is described. Control-measurements are made by using substances prepared artificially.-W. $A$.

5530. Scarpa, Oscar, Radioactivity in the island of Ischia: Ricerca sci., vol. 10, No. 11, pp. 988-991, Rome, 1939.

An account is given of measurements of the radioactivity of thermal . springs and escaping gases on the island of Ischia in the bay of Naples, taken with a view to the possibility of exploring for strong radioactive sources.-E. E. W., Sci. Abstracts, vol. 43, No. 507, 1940.

5531. Westby, G. H., and Scherbatskoy, S. A., Well logging by radioactivity: Oil and Gas Jour., vol. 38, No. 41, pp. 62-64, Tulsa, Okla., 1940.

The radioactive method of logging wells is advantageous because the radioactivity of rocks can be considered unalterable, for temperature and pressure have no effect on the radioactivity of a substance. The ability of radiations emitted by radioactive materials to penetrate through iron makes possible the logging of cased wells also. The authors examine some examples of the radioactive method of logging wells and the diagrams obtained. A table shows the relative radioactivity of several rocks.- $W$. A.

\section{GEOTHERMAL METHODS}

5532. Benfield, A. E., Terrestrial heat flow in Great Britain: Royal Soc. Proc. A, vol. 173, No. 955, pp. 428-449, London, December 1939.

Measurements are described which lead to values of the terrestrial heat flow in five bores in Britain. In the two deepest bores some evidence of the existence of an ice age was found. It is not possible from these measurements, however, to fix the date of the withdrawal of the ice sheet with any certainty, but the indications are consistent with the estimates derived from other evidence. Using 9,000 B. C. as this date to correct the measured heat flows, the mean-equilibrium heat flow is found to be $(1.42 \pm 0.09) 10^{-6} \mathrm{cal} . / \mathrm{cm} .^{2} / \mathrm{sec}$., which is lower than has been previously estimated but is higher than the mean heat flow in South Africa found by Bullard (see abstract 5533). The result of so low a heat flow on temperatures in the granite and basaltic layers is briefly discussed.-Author's abstract. 
5533. Bullard, E. C., Heat flow in South Africa: Royal Soc. Proc. A, vol. 173, No. 955, pp. 474-502, London, December 1939.

The thermal conductivities of 49 rocks from bores in South Africa have been measured. The mean heat flow calculated from these and from Krige's and Weiss' temperature measurements is $1.6 \times 10^{-6}$ cal. $/ \mathrm{cm} .{ }^{2} / \mathrm{sec}$. This is much lower than the values usually quoted but is near Benfield's mean of $0.98 \times 10^{-6}$ for bores in Europe. There is no foundation for the common opinion that the heat flow is lower in South Africa than in Europe. It is likely that many of the other supposed cases of abnormal heat flow are also unfounded. The low value of the heat flow shows that there cannot be more than $12 \mathrm{~km}$. of rock with the radioactivity of surface granite under South Africa. This supports the reality of the "intermediate layer" of seismology and leads to very low temperatures at the base of the granitic layer.-Author's abstract.

5534. Francis, C. F., Temperature gradients related to bottom-hole temperatures: Oil and Gas Jour., vol. 38, No. 42, p. 79, Tulsa, Okla., 1940.

It appears from many observations that there is no uniform temperature gradient that is true for all depths within the range of the holes drilled for oil and gas. Temperature gradients of many wells in the east Texas field are near $1^{\circ} \mathrm{F}$. for each 100 feet, but in the salt-dome districts of both Texas and Louisiana many gradients are near $1^{\circ} \mathrm{F}$. for each 50 feet and many are $1^{\circ} \mathrm{F}$. for 20 to 30 feet. Tables show (1) estimated temperatures of about $212^{\circ} \mathrm{F}$. in wells, and (2) observed bottom-hole temperatures in different oil fields. $-W . A$.

5535. Krige, L. J., Borehole temperatures in the Transvaal and Orange Free State: Royal Soc. Proc. A, vol: 173, No. 955, pp. 450-473, London, December 1939.

Five deep boreholes in which temperatures were measured pass through dolomite, Ventersdorp lava, Witwatersrand quartzite, intrusive diabase, and small thicknesses of other rocks. The geothermic step (increase in depth per degree Centigrade) varies over wide ranges, its mean values being highest in the dolomite and lowest in the lava. It is as a rule small above the water table, especially in the leached dolomite, and generally largest immediately below this level. In the dolomite below the water table the geothermic step is at first very large and in one case negative and then decreases almost continuously downward, the lowest value reached being 310 feet $(95 \mathrm{~m}$.) at its base. This decrease and the negative result both seem to be due to circulation of the ground water. The average below the water table is 382 feet $(116 \mathrm{~m}$.) at Gerhardminnebron, 465 feet $(143 \mathrm{~m}$.) at Driefontan, and 473 feet $(144 \mathrm{~m}$.) at Doornkloof. In the Ventersdorp lava in the Jacoba borehole the geothermic step decreases from 345 feet $(105 \mathrm{~m}$.) below the ground-water level to 217 feet $(66 \mathrm{~m}$.) near its base, the mean being 248 feet $(76 \mathrm{~m}$.), which is also the average at Doornhoutrivier below the first 1,000 feet (300 m.), where the temperatures are affected by gas. In the Witwatersrand quartzites at Gerhardminnebron the range is from 470 to 300 feet (143$91 \mathrm{~m}$.), and the average is 366 feet $(117 \mathrm{~m}$.) at Doornhoutrivier, in both of which holes the thickness of quartzite is small. At Doornkloof the range in the quartzite is from 365 to 335 feet $(111-102 \mathrm{~m}$.) and the average 354 feet $(108 \mathrm{~m}$.), which is also the mean value in two dykes passing through the quartzite. This agreement seems to show that the geothermic step in the quartzite is reduced by the presence of the dykes, and vice versa.-Author's abstract. 
5536. Van Orstrand, C. E., Additional evidence on the relation of temperature to structure in the Salt Creek oil field, Natrona County, Wyo.: Geophysics, vol. 5, No. 1, pp. 47-56, Menasha, Wis., 1940.

Observations of bottom-hole temperatures in approximately 100 deep wells in the Salt Creek field have been made during the past few years. by the Stanolind Oil \& Gas Co. These recent observations confirm and extend in a remarkable manner the results obtained in the summers of 1922 and 1923, when it was found from temperature surveys in 21 wells that the temperatures over a considerable portion of the field were definitely related to the structure.-Author's abstract.

5537. Van Orstrand, C. E., Geothermal methods of estimating the age of the earth: Geophysics, vol. 5, No. 1, pp. 57-79, Menasha, Wis., 1940.

Tables are given by means of which the temperatures in a homogeneous radioactive and nonradioactive earth, subject to a constant. temperature at the surface, can be calculated rigorously with a minimum amount of labor. The rigorous calculations lead to some unexpected results. Among them is the fact that a temperature of $76,000^{\circ} \mathrm{C}$. at. the center of the earth is consistent with observed temperature gradients and that melting of the rocks at a depth of $500 \mathrm{~km}$. is a possible result. of radioactive heat.-Author's abstract.

\section{GEOCHEMICAL METHODS}

5538. Bignell, L. G. E., Exploration for new oil fields stimulated by soil analysis: Oil and Gas Jour., vol. 37, No. 11, pp. 69-70, Tulsa, Okla., 1938.

A general article on the soil-analysis method. The writer notes that. as a new tool it promises to stimulate exploration for new oil reserves, and that like new ideas in general it is not at this date accepted as perfected but is admitted to have possibilities. Examples of soil-analysis: surveys in several localities are given, and the basic theory of the method. is discussed in some detail.-D. W., Annot. Bibl. Econ. Geology, vol. 11, No. 2, 1939.

5539. Heck, E. T., Barium in Appalachian salt brines: Am. Assoc. Petroleum Geologists Bull., vol. 24, No. 3, pp. 486-495, Tulsa, Okla., 1940.

Many Appalachian brines contain appreciable amounts of barium, a fact that has not been generally known until recent years. Barium has been found in brines from rocks of Silurian, Devonian, Mississippian, and Pennsylvanian age. Apparently the barium was originally present. in the sediments as barite, and progressive destruction of the sulphate radicle brought the metal into solution.

It has been shown that the areas most productive of oil and gas also. produce brines that contain the largest percentages of barium.-Author's. summary.

5540. Lundberg, Hans, The future of geophysics in the light of new developments: Canadian Min. Jour., vol. 61, No. 4, pp. 225-226, Gardenvale, Quebec, 1940.

The author describes the relation between the elements in plants: and in native soil, a relation that makes it possible to obtain not only qualitative but also quantitative data on the contents of the various elements in the rock and soil. The method in general consists of systematically collecting, from the area to be investigated, samples of plant. material from either living or dead plants. The material is then burned! 
and the ashes are subjected to a spectroanalysis, from which comparative values are obtained for the average concentrations of one or more desired elements in a large volume of the ground at the place where the sample was taken. The method is applicable to areas where thin overburden covers the bedrock formation. The metals that can be located, and from which results have already been obtained, are manganese, vanadium, molybdenum, tungsten, tin, nickel, silver, lead, zinc, copper, and gold. The cost of a survey of this kind is between $\$ 100$ and $\$ 200$ per square mile, depending on the detail required.-W. $A$..

5541. Pike, R. W., and others, Source rocks of petroleum-a symposium of opinion: Am. Assoc. Petroleum Geologists Bull., vol. 24, No. 3, pp. 496-503, Tulsa, Okla., 1940.

Eugene McDermott recently published in Geophysics (see Geophys. Abstracts 99, No. 5247) an article entitled "Concentrations of hydrocarbons in the earth." As a result of soil-analysis studies in the LlanoBurnet uplift of Texas and in the Sierras of California, McDermott observed that hydrocarbon gases, especially those of an unsaturated type such as ethylene, not only occurred generally in the sedimentary strata investigated but were even on top of and in basement rocks. This information "led to a series of investigations and experiments which resulted in the gathering of considerable data concerning the concentrations of hydrocarbons as well as minerals near the surface of the earth. From such observations a hypothesis was derived which in a very substantial manner accounts for the accumulations found near the earth's surface, as well as at depth."

The paper caused comment and led to a discussion in which thoughts and ideas on this problem were summarized and to which many leading authorities contributed opinions.-W. $A$.

5542. Rosaire, E. E., Geochemical well logging: Oil and Gas Jour., vol. 38, No. 50, pp. 114-120, Tulsa, Okla., 1940.

After a general description of the technique of geochernical prospecting and geochemical well logging, the author summarizes the practical utility of the latter as follows: (1) "Dry" holes can be graded qualitatively as to their closeness to a petroleum deposit; (2) zones can be recognized that are practically barren of petroleum and do not need to be cored; (3) zones can be recognized that contain significant amounts of petroleum hydrocarbons and that, therefore, should be carefully cored; (4) the vertical extent, of such potentially significant zones can be recognized; (5) the geochemical well $\log$ distinguishes between the high pressure due to gas an'd the high pressure due to salt water; (6) "Dry-hole prospecting" is made possible by grading the geochemical logs of dry holes on a prospect as to their qualitative proximity to a petroleum deposit, if one is near; (7) significant structural variations cannot be expected at shallow depths over stratigraphic traps and deep-seated low-relief structures; (8) in effect, the geochemical well log extends the vertical penetration of the bit 500 to 1,000 feet and laterally as much as onefourth to one-half mile, and permits qualitative estimates of the extent of a petroleum deposit in those adjacent sediments that are not penetrated by the bit; (9) the geochemical well log contributes independent quantitative evidence as to the presence or absence of "shows" and, if such are present, the log indicates the relative percentage of "gas" and "distillate" hydrocarbons throughout the section in which such appreciable concentrations occur.-W. $A$. 
5543. Simmons, H. F., Scope of soil analysis increased during year: Oil and Gas Jour., vol. 38, No. 42, p. 54, Tulsa, Okla., 1940.

It is estimated that during 1939 about $\$ 250,000$ was spent in research on all phases of chemical prospecting and about 300 surveys were made. During this period the failures on prospects that were recommended by soil analyses nearly equaled the discoveries. Looking to the future, the author expects some very interesting and worthwhile developments in laboratory technique and believes that the use of soil analysis as a part of exploration programs will be continued during 1940. $-W$. $A$.

5544. Stormont, D. H., Operation of a Gulf coast field on soil-survey information: Oil and Gas Jour., vol. 38, No. 10, pp. 28-29, Tulsa, Okla., 1939.

The author cites the discovery of an oil field in San Patricio County, southwestern Texas, as an example of the use of chemical prospecting in exploring for oil. He points out the close association that exists between hydrocarbon concentration and mineralization of the soil (soluble mineral content). High oil content and high mineralization of the soil seem to go together and thus afford two entirely independent methods of chemical testing, one of which is based on organic and the other on inorganic contents. He explains briefly the association of the two methods. $-W$. $A$.

\section{UNCLASSIFIED METHODS AND TOPICS RELATED TO GEOPHYSICS}

5545. Bentz, A., and Closs, H., Erdöl und geophysikalische Reichsaufnahme in Grossdeutschland [Petroleum and governmental geophysical survey in Germany]: Oel und Kohle, vol. 35, No. 41, pp. 731-739, Berlin, 1939.

An account of the gradual development of the geophysical survey of Germany to the end of 1938 has already been published by Closs and Wolff (see Geophys. Abstracts 98, No. 5097). Continuation of the survey to the end of 1939 is discussed in this article. Results of pendulum, magnetic, and torsion-balance measurements to the end of September 1939, and results of gravimeter and seismic measurements to the end of August 1939, are shown in accompanying maps. Special maps show the general distribution of oil fields in Germany and salt structure of the Allen region.-W. $A$.

5546. Born, W. T., Geophysical application in the production of oil: Oil Weekly, vol. 97, No. 5, p. 76, Houston, Tex., 1940.

This paper comments briefly upon the importance of geophysical data and methods in solving problems concerned with the production of oil. Among the methods discussed are included electrical logging of uncased wells, thermometric surveys of both completed and uncompleted wells, the use of sound-reflection methods for determining the fluid level in producing wells, and the recently introduced method of logging formations behind casing in completed wells by recording their relative radioactivity. Mention is made of current work on the possibility of logging formations by determining their acoustic properties.-Author's abstract in Oil and Gas Jour., vol. 38, No. 48, 1940.

5547. Cohen, E. R., Geologic investigations by deep drilling southeast of the village of Sultanci, near Provadia, in northeastern Bulgaria, according to geophysical information [in Bulgarian]: Bulgarian Geol. Soc. Rev., vol. 10, part 3, pp. 159-178, Sofia, 1938. 
Geophysical investigations made in 1936 in the Mirovo-Sultanci depression (basin of the Provadia River) are described. An elliptical structure, the cross section of which represents a horst, was established southeast of the village of Sultanci. The horst structure was supposed to be caused by the deep-seated salt stock. Deep borings, based on two very promising geophysical profiles, were made to solve this question. No salt was found. Geologic determination of drill holes agreed well with geophysical determinations of the structure. The two sets of information differed only with regard to depth. Three tables showing a plan of the area investigated and several profiles are given.-W. $A$.

5548. Macelwane, J. B., Geophysical education in a Department of Geophysics: Geophysics, vol. 5, No. 1, pp: 80-90, Menasha, Wis., 1940.

The author discusses in detail the subject of geophysical education; some of the complicated problems to be solved by a geophysicist; the backgrounds of a geologist and a geophysicist and cooperation between them; the independence of geophysics as a distinct science in its own right; and many other matters.

In the second part of this interesting article the author briefly describes geophysical education in foreign countries (France, Germany, Italy, England, Japan, and Canada) and in the United States.

Summarizing, he says: "I should like to make a strong plea for the organization of all geophysical education under distinct departments of geophysics manned by trained geophysicists both in our universities and in our engineering schools; for it is only in a geophysical atmosphere that the distinctive viewpoints and methods of geophysical science can be expected to bear their full fruit."-W. $A$.

5549. Oddone, Emilio, Discontinuita, densità e compressibilità cubica nell' interno della terra [Discontinuity, density, and cubic compressibility inside the earth]: Geofisica pura e applicata, vol. 1, No. 3/4, pp. 155-174, Messina, 1939.

The author discusses (1) discontinuity in the earth's crust; (2) rate of change of density as a function of depth; (3) comparison with the distribution of density as generally accepted; (4) stratification of heavy masses in the earth's crust and in the central part of the earth; (5) rising of rock magmas and heavy minerals toward the crust; and (6) deductions concerning relations between pressure and cubic compression. Tables and diagrams are given.-W. $A$.

5550. Pictorial story of geophysical prospecting in India [editorial note]: Oil Weekly, vol. 97, No. 2, pp. 156-161, Houston, Tex., 1940.

Geophysical explorations are now used not only in the potential producing countries but throughout the world. Some of the hazards encountered by one geophysical party working in India are illustrated.W. A.

5551: Schoene, Hans-Joachim; Das geophysikalische Laboratorium der Reichs. stelle für Bodenforschung [National' geophysical laboratory for geologic investigation]: Oel und Kohle, vol. 35, No. 41, pp. 759-761, Berlin, 1939.

The author gives an outline of the methods and the sphere of application of the national geophysical laboratory. He summarizes the extent of the work, by which 233 borings and 2,350 core samples were investigated as follows: Determinations of elasticity (since 1935), about 620; 
of specific gravity (since 1935), 2,280; of density (since 1935), 2,090; of total volume of porosity (since 1936), 2,090; of effective volume of porosity (since 1937), 670; and of the content of salt (since 1939), 109; investigations of the size of grains (since 1938), 76; measurements of permeability (since 1939), 41; and of susceptibility (since 1939), 114. He includes photographs of a few instruments used in the laboratory.W. A.

5552. Schonland, B. F. J., The Bernard Price Institute of Geophysical Research: Terres. Magn. and Atmos. Electr., vol. 43, No. 4, pp. 477-482, Baltimore, Md., 1938.

A complete description of the newly established geophysical research laboratory set up by the Carnegie Corporation of New York and Dr. B. Price, called the Bernard Price Institute of Geophysical Research. This center is located on the campus of the Witwatersrand University at Johannesburg. A permanent staff with technical and mechanical (workshop) assistants has been set up. The Institute was officially opened in October 1938. A program of investigation in atmospheric electricity, seismology, and crustal magnetism, with a limited activity in applied geophysics, is under way. A plan and description of the excellently arranged new laboratory building is shown and described. $-D . W$., Annot. Bibl. Econ. Geology, vol. 11, No. 2, 1939.

5553. Science of today's oil-field exploration [editorial note]: Oil Weekly, vol. 97, No. 5, pp. 24-31, Houston, Tex., 1940.

Some exploration work by geophysicists is shown in a series of photographs.- $W . A$.

5554. Simmons, H. F., Marsh buggy for use in Gulf coast fields: Oil and Gas Jour., vol. 38, No. 41, p. 71, Tulșa, Okla., 1940.

The writer describes the development of the "marsh buggy," a truck that is capable of carrying a heavy load over hard or soft ground or through water. This buggy is used in geophysical exploration in some areas of the Gulf coast region for transporting the shot-hole drilling and recording equipment over swamps, dry land, and small, shallow lakes. Photographs show a marsh buggy in operation and some of its parts.W. A.

5555. Todd, J. D., and Roper, F. C., Sparta-Wilcox trend, Texas and Louisiana: Am. Assoc. Petroleum Geologists Bull., vol. 24, No. 4, pp. 701-715, Tulsa, Okla.; 1940.

The major portion of this recently revived trend in the lower Eocene of the upper Gulf coast of Texas and Louisiana is considered to lie between the 5,000-foot contour on the north and the 10,000-foot contour on the south. Sand conditions are such that this trend may be comparable in productive possibilities with the other major producing trends of the Gulf coast. From their observation of the available evidence, the writers believe the following conclusions are justified at this time: (1) Conditions are more favorable for the accumulation of oil in the Sparta and Wilcox sands between the 5,000-foot levels (where fresh water is present) and the 10,000 -foot levels (where shale appears); (2) improved seismograph instruments, better shooting technique, new velocity curves and other improvements, coupled with a better understanding of the area, will result in making the seismograph as effective an instrument in the trend as it now is in the coastal region; (3) the 
new gravimeters will work well in the trend and will greatly help in rapidly and economically isolating the areas of probable structural deformation; (4) improved methods of soil analysis will assist in the locating of both structural and stratigraphic traps; (5) through. the combined use of all of these new and improved methods the real effective exploration of this trend is just beginning.

There appears no reason to doubt that many more large, flat structures will be found, and it appears very likely that the ultimate producing area in the trend will rival that in the coastal region.-Authors' abstract and conclusions.

5556. von Zwerger, Rudolf, Die geophysikalische Aufnahmetätigkeit in polnischen erdölhöffigen Gebieten [Geophysical-prospecting activity in promising oil regions of Poland): Oel und Kohle, vol. 35, No. 37, pp. 697-701, Berlin, 1939.

The writer considers the following two regions to be the most promising in Poland: (1) The Carpathian foreland, and (2) the region of the lower Vistula (Province of Posen).

After outlining briefly the history and geology of the two regions, he shows in accompanying maps and profiles the results of investigations made in the Carpathian foreland by gravimetric, seismic, magnetic, and electrical methods of prospecting. He concludes that the investigations made thus far are not sufficient and must be extended on a larger scale, especially by the gravimetric and seismic-reflection methods.

No definite results have been published yet from the investigations made by gravimetric and seismic methods in the region of the lower Vistula.-W. A.

5557. Wantland, Dart, Geophysics education at an engineering institution: Geophysics, vol. 5, No. 1, pp. 91-101, Menasha, Wis., 1940.

The background and development of the courses of instruction in exploration geophysics at the Colorado School of Mines as well as the limiting factors in shaping a geophysics curriculum and the time devoted to various phases of the graduate courses in applied geophysics offered are discussed. The present positions occupied by geophysics graduates of the institution after 12 years of operation of the Geophysics Department are shown, and a summary is given of the replies of these men to an inquiry as to their opinion of the instruction they received.-Aulhor's abstract.

5558. Weaver, Paul, Exploration geophysics-10 years with the Society: Oil Weekly, vol. 97, No. 5, pp. 62-66, Tulsa, Okla., 1940.

The author describes the organization of the Society of Exploration Geophysicists and its development up to the present time, and he presents brief biographies and photographs of all past presidents of the Society. $-\dot{W} . A$.

\section{NEW PUBLICATIONS}

5559. American Geophysical Union, Special basement-surface contour map of eastern and central United States. Copies are purchasable through Dr. J. A. Fleming, General Secretary; Am. Geophys. Union, 5241 Broad Branch Road, Washington, D. C. Price, \$3.50.

This contour map (contour interval, 1,000 feet; map scale, $1: 2,500$,000 ) shows the approximate topographic and structural relief of the 
"basement" surface between the Atlantic seaboard and the west rim of the Colorado Plateau region.- $W$. $A$.

5560. Earthquake notes, J. H. Nelson, editor, vol. 11, No. 3, 8 pp., Seismol. Soc. America, Eastern Section, Washington, D. C., 1940.

This issue contains the following notes: (1) Spring meeting, 1940; (2) New committees of the Eastern Section; (3) Methods and operations; (4) Earthquakes at Boulder Dam; (5) Seismographs for Shasta Dam area; (6) San Francisco-Oakland Bay Bridge; (7) Seismic investigation, North Atlantic Ocean; (8) New seismograph for the Fiji Government; (9) Disastrous earthquakes, January-June 1938; (10) Deepfocus earthquake of May 8, 1938, by W. A. Lynch; (11) Trends in earthquake insurance and engineering since 1933, by A. C. Chick; (12) Density of seismograph stations, by H. Landsberg; (13) Earthquake near Seattle; (14) New Jersey shock of November 14, 1939; (15) Earthquake in Turkey; (16) Southern California earthquakes; (17) Strong-motion records; (18) Epicenters; and (19) Items of interest. $-W . A$.

5561. Maurain, Charles, Annales de l'Institut de Physique du Globe de l'Université de Paris et du Bureau Central de Magnétisme Terrestre [Annals of the Institute of the Physics of the Globe at the University of Paris and of the Central Bureau of Terrestrial Magnetism], vol. 17, 113 pp., Paris, Presses Universitaires de France, 1939.

This volume of the Annals contains the following articles: (1) Magnetic observations made during 1937 at the Observatory of Chambonla-Forêt, by L. Eble; (2) Magnetic observations made during 1937 at the Observatory of Nantes, by E. Tabesse; (3) Summary of seismologic observations made in 1937 at the Observatory of Parc Saint-Maur, by C. E. Brazier and L. Genaux; (4) Summary of meteorological observations made in 1937 at the Observatory of Parc Saint-Maur, by C. E. Brazier; (5) Summary of actinometric observations made in 1937 at the Observatory of Parc Saint-Maur, by C. E. Brazier; (6) On the terrestrial electric phenomena at the Observatory of 'Val-Joyeux based on observations !made during a period of 12 years; electric field; conductivity; ionization; by Ch. Maurain, Ed Salles, Mme. Salles-Homery, G. Gibault, and P. Charczenko; (7) Observations of the electric field of the atmosphere in the region of the Atlantic Ocean and in the Mediterranean, by J. Rouch; (8) Magnetic observations made during 1937 at the Observatory of Tananarive (Madagascar), by Ch. Poisson; (9) Recording of the terrestrial magnetic field at the Observatory of Tamanrasset-The results obtained from 1934 to 1937, by J. Coulomb, J. Dubief, A. Lasserre, and P. Queney; (10) Magnetic measurements made at Hoggar and the regions surrounding it, by J. Dubief.

The volume is supplemented by graphs showing the principal magnetic perturbations in 1937 that were obtained from registrations at the Observatory of Chambon-la-Forêt.-W. $A$.

5562. Nickles, J. M., Siegrist, Marie, and Tatge, Eleanor, Bibliography and index of geology, exlcusive of North America, 1938, vol. 6, 471 pp., New York, Geol. Soc. America, 1939. Price, $\$ 2.30$.

This volume contains references to literature published in 1938 on the geology of the world, except North America. It has both an alphabetic author list and a comprehensive subject index. $-W . A$ : 


\section{PATENTS}

5563. Recording apparatus and method; Raymond D. Elliott, Long Beach, Calif., assignor by mesne assignments to Schlumberger Well Surveying Corporation, Houston, Tex., a corporation of Delaware: U. S. patent 2,170,857, issued August 29, 1939.

This invention relates to a method of producing a log of geological formations penetrated by a hole containing conductive liquid, which comprises moving a pair of vertically spaced electrodes along said hole; passing current from one of said electrodes into the surrounding formation, whereby an electric field is produced in the formation surrounding the electrode; moving a record-receiving strip in a predetermined direction in synchronism with the movement of said electrodes in the hole; recording a line on said strip as it moves past a fixed path transverse to the strip and varying the lateral position of the point of recording said line in response to variations in resistance to passage of said current from said one electrode; identifying longitudinal points on said record with respect to the position of said one electrode in the hole at the instants of recordation of said line at those points; simultaneously recording a second line on said strip as it moves past a second fixed path transverse to the strip; and varying the lateral position of the point of recording said second line in response to variations in the potential of the other electrode, in which said second transverse path is spaced longitudinally from said first transverse path, a scale distance equal to a predetermined fraction of the vertical spacing between said electrodes. Claims allowed, 15.

5564. Exploration by incremental wave distortion; Robert Saibara, Solomon Bilinsky, and W. G. McLarry, Houston, Tex., assignors to Esme E.

Rosaire, Houston, Tex.: U. S. patent 2,177, 346, issued October 24, 1939.

This invention relates to geophysical exploration by electrical methods and pertains particularly to exploration for geologic structure by causing an electric current to flow in the earth and observing the wave distortion of potential detected in the area subject to the current, the improvement comprising subjecting the detected potential to an adjustable additional distortion; observing the resultant wave shape; and varying the additional distortion until the resulting wave approaches a predetermined wave shape over at least a portion of the time during which the amplitude varies. Claims allowed, 12.

5565. Feedover device; Ludwig W. Blau, W. D. Mounce, and W. M. Rust, assignors to Standard Oil Development Co.: U. S. patent 2,180,949, issued November 21, 1939.

This invention relates to improvements in apparatus and method of recording seismic vibrations, in which the vibrations are received at a plurality of detectors, converted into pulsations of electrical energy, and the pulsations so obtained are recorded-the steps of passing the pulsations generated by the several detectors directly to individual recorders until the first vibrations arriving at the several detectors are recorded and thereafter passing the electrical pulsations resulting from the arriving vibrations at the several detectors through connected electrical impedances before transmitting them to the recording ineans. Claims allowed, 7. 
5566. Multiple gravity meter; Frank G. Boucher, Houston, Tex., assignor to Standard Oil Development Co., a corporation of Delaware: U. S. patent 2,183,115, issued December 12, 1939.

This invention relates to a gravity meter comprising a weight system, including arms protruding at right angles from a hub and a weight carried by each arm; aligned, horizontally disposed tension springs, the adjoining ends of which are secured to the hub; means for applying tension and torque to the opposite ends of the springs, whereby the weight system is maintained in position by the tension and torque of the springs with one arm substantially horizontal and the other arm extending vertically upwardly, whereby variations in the pull of gravity affect the position of the weight system; means for restoring the system to its original position, including a tension spring secured to the weight system; and means for adjusting the tension of the spring to restore the system to its original position after displacement by gravity. Claims allowed, 4 .

5567. Borehole thermometer; Leo V. Uhrig, Houston, Tex., assignor to Standard Oil Development Co., a corporation of. Delaware: U. S. patent $2,183,126$, issued December 12, 1939.

This invention relates to a borehole thermometer comprising a recording chamber and a measuring chamber sealed from each other; an inner chamber in said measuring chamber having its walls spaced from the walls of the measuring chamber; a heat-sensitive fluid filling said inner chamber; a rod connected with said piston passing into the recording chamber; and a heat-sensitive fluid in the annular space between the wall of the measuring chamber and the wall of the inner chamber. Claims allowed, 2.

5568. Multiple galvanometer; Carl A. Heiland, Denver, Colo., assignor. to Heiland Research Corporation, Denver, Colo., a corporation of Colorado: U. S. patent 2,183,934, issued December 19, 1939.

This invention relates to a movable element for galvanometers, comprising a suspension strand of conducting material having between its ends a rebent portion extending to one side of the strand; a nonconducting strip carried by the strand and bridging the open side of the rebent portion; and a mirror mounted on the nonconducting strip. Claims allowed, 13.

5569. Method of exploration for buried deposits; Leo Horvitz, Houston, Tex., assignor to Esme E. Rosaire, Houston; Tex.: U. S. patent 2,183,964, issued December 19, 1939.

This invention relates to the method of exploration for carboniferous deposits, which comprises the steps of taking samples of soil at or near the surface; treating said samples to evolve in gaseous form constituents entrained therein in normally nongaseous form and which are due to leakage from said deposits; subjecting the evolved gases to analysis; and determining the amount and presence of hydrogen as an indication of proximity of the respective samples to the sought deposits. Claims allowed, 4 .

5570. Seismic surveying; John E. Owen, Tulsa, Okla., assignor to Geophysical Research Corporation, New York, N. Y., a corporation of New Jersey: U. S. patent 2,184,313, issued December 26, 1939 .

This invention relates to an apparatus for receiving and recording artificial seismic waves, comprising a pair of geophones arranged so as 
to be substantially simultaneously actuated by earth motion, one of said geophones being responsive only to the horizontal component of said earth motion and the other geophone being responsive only to the vertical component of said earth motion; a single recorder; connections between both said geophones and said recorder for impressing the outputs of both geophones on said recorder; and means in said connections for balancing out the effects of the surface waves received by said geophones. Claims allowed, 9.

5571. Multiple-component gravity balance; Ludwig W. Blau, Houston, Tex., assignor to Standard Oil Development Co., a corporation of Delaware: U. S. patent 2,185,582, issued January 2, 1940.

This invention relates to a gravity balance comprising a beam; a weight secured directly to one end of the beam; a weight suspended from the other end of the beam; a suspension system for the beam comprising shoulders protruding laterally from the beam; a bar disposed above the shoulders suspending the shoulders by spaced filaments, whereby vertical deflection of the beam is permitted; and a filament attached to an intermediate portion of the bar suspending the bar in a horizontal position, whereby horizontal deflection of the beam is permitted. Claims allowed, 7 .

5572. Goniometric device for determining the dip and strike of strata from bore core; Frank Humphreys, Klerksdorp, Union of South Africa: U. S. patent 2,186,67\%, issued January 9, 1940.

This invention relates to a goniometric device provided with a holder for receiving a piece of bore core; a device for indicating the inclination of the axis of said holder; means for rotating said holder in a vertical plane until the axis of the holder assumes a desired inclination; a device for indicating the magnetic bearing of the axis of said holder; means for rotating said holder until its axis assumes a desired magnetic bearing; and directionally indicative means arranged to be set to a desired magnetic bearing. Claims allowed, 8 .

5573. Method and apparatus for electrical prospecting; Carl A. Heiland, Denver, Colo., assignor to Heiland Research Corporation, Denver, Colo., a corporation of Colorado: U. S. patent 2,189,377, issued February 6, 1940.

In a system for electrical prospecting-including spaced, grounded electrodes for creating an electric field in the ground and means for supplying current to the electrodes-a series of three potential pick-up electrodes arranged linearly and at equal spaces, the central electrode being spaced from the nearest field-creating electrode a distance that is equal to a multiple of the distance between the electrodes, and a bridge connected in circuit with the three electrodes for balancing the current flow between them. Claims allowed, 5 .

5574. Seismograph blasting cap; John P. Minton, Dallas, Tex., assignor by mesne assignments to Socony-Vacuum Oil Co., Inc., New York, N. Y., a corporation of New York: U. S. patent 2,189,741, issued February 6, 1940.

In an apparatus for seismic survey, including a blasting circuit; a source of power for energizing the circuit; a recorder for recording seismic waves and a communication circuit connecting the blasting circuit with the recorder; and improved blasting structure comprising a detonating substance; a plurality of conductors extending into said structure; 
fusible means lying in contact with the detonating substance and connected to the conductors; frangible electrical conducting means disposed within the structure and connected to the conductors to normally maintain the blasting circuit closed, independent of the fusible means, said frangible means being so positioned with respect to the detonating substance that it will be ruptured coincident with the detonation of the substance to generate a transient voltage that will be communicated to the recorder as an indication of the exact instant of detonation of the explosive charge. Claims allowed, 2.

5575. Apparatus for determining pressure and temperature in a well; George $\mathrm{H}$. Ennis, Long Beach, Calif., assignor of one-half to Robert V. Funk, Long Beach, Calif.: U. S. patent 2,190,260, issued February 13, 1940.

In an apparatus for determining, at the surface of the ground, phenomena which exist in a borehole, the combination of an electric circuit, a part of which extends into said borehole; circuit-breaking means operable to break said circuit; indicating means in said circuit; and apparatus adapted to be lowered into said borehole to depths where said determination is to be made, said apparatus including pressure-responsive means, temperature-responsive means, and switch means actuated by the successive opening and closing of said circuit, for first connecting said pressure-responsive means to said circuit and then said temperatureresponsive means to said circuit and also for closing said circuit at its lower end with said pressure- and temperature-responsive means disconnected from said circuit. Claims allowed, 3.

5576. Method of determining the presence of oil; Gennady Potapenko, Pasadena, Calif., assignor to Geo-Frequenta Corporation, a corporation of Delaware: U. S. patent 2,190,320, issued February 13, 1940.

This invention relates to a method of oil prospecting, which includes subjecting the earth to a polarizing electromotive force and determining the dependence upon time of the resultant earth polarization. Claims allowed, 4.

5577. Method and apparatus for geophysical prospecting; Gennady Potapenko, Pasadena, Calif., assignor to Geo-Frequenta Corporation; a corporation of Delaware: U. S. patent 2,190,321, issued February 13, 1940.

This invention relates to the method of geophysical prospecting, comprising polarizing the earth for a limited time-period; applying electromotive force to the earth during two limited time-periods during discharge of the earth polarization following termination of said polarizing period; and measuring earth polarization by observing the difference in currents flowing in circuit with the electromotive force during said two time-periods. Claims allowed, 14.

5578. Method of geophysical prospecting; Gennady Potapenko, Pasedena, Calif., assignor to Geo-Frequenta Corporation, a corporation of Delaware: U. S. patent 2,190,322, issued February 13, 1940.

This invention relates to a method of geophysical prospecting, comprising subjecting the earth to polarizing applications of a unidirectional electromotive force during polarizing periods of different duration, and measuring the resultant earth polarization at a plurality of times during the discharge of said polarization following polarizing applications of each duration, whereby is determined a relation between polarization and time during the build-up and discharge of polarization. Claims allowed, 7. 
5579. Method and apparatus for geophysical prospecting; Gennady Potapenko and Donald Folland, Pasadena, Calif., assignors to Geo-Frequenta Corporation, a corporation of Delaware: U. S. patent 2,190,323, issued February 13, 1940.

This invention relates to a method of geophysical prospecting, comprising polarizing the earth for a limited time-period by application thereto of a unidirectional electromotive force and continuously measuring the instantaneous value of the resultant earth polarization during discharge of said polarization following said polarizing period. Claims allowed, 9.

5580. Method of geophysical prospecting; Glen Peterson, Pasadena, Calif., assignor to Geo-Frequenta Corporation, a corporation of Delaware: U. S. patent 2,190,324, issued February 13, 1940.

This invention relates to a method of geophysical prospecting, comprising subjecting the earth through spaced electrodes to intermittent polarizing applications of a unidirectional electromotive force of constant duration; intermittently measuring between spaced points in the earth the potential difference due to the resultant earth polarization during measuring periods of constant duration, following said polarizing applications by a constant time interval; and repeating said intermittent measurement of potential difference employing measuring periods following said polarizing applications by time intervals having a plurality of values different from said first-mentioned time interval, the repetitions of said measurements being sufficient in number to establish a relation between the measured potential difference and said time interval. Claims allowed, 8.

5581. Borehole surveying instrument; Frank Humphreys, Klerksdorp, Transvaal, Union of South Africa: U. S. patent 2,190,790, issued February 20, 1940.

The present invention relates to a borehole surveying instrument including two separate devices arranged to take up positions depending upon the inclination and magnetic bearing of the axis of the lower end of the borehole, respectively; means of recording said positions; and means for marking a radial line on a substantially transverse surface at the lower end of the borehole. Claims allowed, 12.

5582. Apparatus for determining the inclination and direction of a hole; Gennady Potapenko, Pasadena, Calif: U. S. patent 2,190,950, issued February 20, 1940.

This invention relates to an apparatus for determining inclination, comprising a body adapted to assume the inclination to be measured; means for generating an elastic vibration; means for varying the frequency of said elastic vibration in response to the inclination of said body; and frequency-measuring means responsive to said elastic vibration. Claims allowed, 9.

5583. Gravity measuring instrument; Stephan Baron von Thyssen-Bornemisza, Hanover, Germany, assignor to Shell Development Co., San Francisco, Calif., a corporation of Delaware: U. S. patent 2,190,959, issued February $20,1940$.

This invention relates to a gravity meter comprising a lever; a fulcrum supporting said lever; a mass attached to said lever on one side of said fulcrum; spring means connecting said lever to a fixed point and adapted to oppose any downward movement of said mass; a projecting member 
attached to the lever in a plane passing through the fulcrum and perpendicular to the longitudinal axis of the lever; and a second mass supported by said member. Claims allowed, 4 .

5584. Method and apparatus for surveying the formations traversed by a borehole; Conrad Schlumberger, Paris, France, Anne Marguerite Louise Doll, administratrix of said Conrad Schlumberger, deceased, assignor by mesne assignments to Schlumberger Well Surveying Corporation, Houston, Tex., a corporation of Delaware: U. S. patent 2,191,119, issued February 20, 1940.

This invention relates to the method of determining the local lithological character of the rocks located at different depths in a borehole, which method comprises causing an elastic wave emission in the borehole and obtaining indications at two points close to each other and to each considered depth of the value of at least one local parameter of the elastic wave transmitted by the rocks constituting the wall of the hole at the said depth. Claims allowed, 31.

5585. Method of geological survey; Louis B. Slichter, Belmont, Mass., assignor to Schlumberger Well Surveying Corporation, Houston, Tex., a corporation of Delaware: U. S. patent 2,191,120, issued February 20, 1940.

The present invention relates to a method of determining the geologic structure of the earth in the vicinity of a drill hole, which comprises successively producing sound vibrations at spaced points in the drill hole; receiving at a single fixed position from said spaced points therein the waves produced at said points; and comparing the energy received from said points. Claims allowed, 1 .

5586. Geological surveying apparatus; Louis B. Slichter, Belmont, Mass., assignor. to Schlumberger Well Surveying Corporation, Houston, Tex., a corporation of Delaware: U. S. patent 2,191,121, issued February 20, 1940.

This invention relates to the exploration of drill holes and, more particularly, to the determination of the properties and characteristics of the various strata traversed by a drill hole by the use of compressional wave energy. A device of the type described in this invention contains a cable; a streamline body composed of two parts and adapted to fit over the cable, the cable passing centrally therethrough; means for clamping the streamline body together about the cable; and means providing a sound-receiving device within the streamline body having a diaphragm contained within the surface of the streamline body. Claims allowed, 3 .

5587. Temperature indicator for wells; Ralph W. Lohman, South Pasadena, Calif.' assignor to Lane-Wells Co., Los Angeles, Calif., a corporation of Delaware: U. S. patent 2,191,765, issued February 27, 1940.

This invention relates to a temperature indicator for wells, comprising a helical resistance coil adapted to change its resistance in response to change in its temperature; a high-pressure resistance case therefor comprising relatively thin outer and inner shells covering the outer and inner sides of said coil and contacting each other between convolutions of said coil and forming bridges of rudimentary cross section over the convolutions of said coil, capable of withstanding extreme hydrostatic pressure, the outer and inner surfaces of said outer and inner shells, respectively, being exposed to well pressures; and means electrically associated with said coil for indicating the temperature thereof. Claims allowed, 4. 
5588. Method and apparatus for electrical exploration of the subsurface; John Jay Jakosky, Los Angeles, Calif.: U. S. patent 2,192,404, issued March $5,1940$.

This invention relates to the method of electrical exploration of the subsurface, which comprises passing an electric current through the earth between a pair of energizing electrodes, spaced a known distance from one another along the earth's surface so as to create a quantity at a fixed position on the earth's surface; repeatedly changing the position of at least one of said electrodes and passing current between said electrodes so as to repeatedly vary the path of the current and create a multiplicity of successive values of said quantity at said fixed position; and taking a multiplicity of measurements while said current is flowing through the successive paths, indicative of the effect of variations in the subsurface upon the value of said created quantity at said fixed position as the path of current is so varied. Claims allowed, 15.

5589. Geophysical prospecting method; Esme E. Rosaire and Leo Horvitz, Houston, Tex., said Horvitz assignor to said Rosaire: U. S. patent 2,192,525, issued March 5, 1940.

The present invention relates to the method of detecting subterranean deposits from which leakage of emanations occur, which comprises taking soil samples from selected points in a predetermined area; confining the respective-soil samples from air contamination; removing said samples from confinement; and analyzing the samples with respect to gases contained in the samples directly related to said deposits. Claims allowed, 15.

5590. Seismic surveying; Arland J. Innes, Fort Worth, Tex., assignor to Geophysical Research Corporation, New York, N. Y., a corporation of New Jersey: U. S. patent 2,192,972, issued March 12, 1940.

This invention relates to the method of seismic surveying by correlation of reflection records produced by detonation of explosive charges in boreholes in an area characterized by a surface layer of such nature that a seismic charge detonated at some depth or depths in the borehole produces a seismic record which is not correlatable with records obtained by detonating seismic charges in other similar boreholes; the procedure which consists in making a resistivity-depth graph of the materials traversed by a test shot hole; determining the depth at which the charge should be planted in said test hole to obtain best reflection quality and establishing the corresponding point on said test hole resistivity-depth graph; making resistivity-depth graphs of other shot holes; selecting the point on each. of such graphs corresponding to said point on the test shot-hole resistivity-depth graph; establishing the depth in each shot hole corresponding to the point so selected; and making records of the seismic waves produced by detonating explosive charges planted at said selected depths. Claims allowed, 3 .

5591. Seismic surveying; Arland J. Innes, Fort Worth, Tex., assignor to Geophysical Research Corporation, New York, N. Y., a corporation of New Jersey: U. S. patent 2,192,973, issued March 12, 1940.

This invention relates to the method of seismic surveying by correlation of reflection records produced by detonation of explosive charges in boreholes in an area characterized by a surface layer of such nature that a 
seismic charge detonated at some depth or depths in the borehole produces a seismic record which is not correlatable with records obtained by detonating seismic charges in other similar boreholes; the procedure which consists in drilling a test hole; making a natural-earth potential-depth graph of the material traversed by said test hole; shooting charges at different depths in said test hole; making a record of the seismic waves produced by each shot; determining the depth of the shot which produces the best record; establishing the corresponding point on said test-hole natural-earth potential-depth graph; drilling additional shot holes; making a natural-earth potential-depth graph for each additional shot hole; selecting the point on each such graph which correlates with said point on the test-hole natural-earth potential-depth graph; establishing the depth in each additional shot-hole corresponding to the point so selected; and shooting an explosive charge at such depth in each additional shot hole. Claims allowed, 2.

5592. Frequency multiplication system for seismic recording; John P. Minton, Dallas, Tex., assignor by mesne assignments to Socony-Vacuum Oil Co., Inc., New York, N. Y., a corporation of New York: U. S. patent 2,193,769, issued March 12, 1940.

This invention relates to a device for geophysical prospecting, in which means are provided to generate seismic waves, and additional means are provided to detect them after they have passed through a portion of the earth and to amplify and record them, the improvement that comprises a frequency-multiplying circuit connected so as to multiply the frequency of the detected waves, and a filter circuit connected to exclude the multiplied ground-roll waves from the recorder. Claims allowed, 1.

5593. Method of measuring the inherent terrestrial magnetism of the earth's crust; Robert E. Lee, Coleman, Tex., assignor of 50 percent to Joseph H. Reynolds, Cisco, Tex.: U. S. patent 2,196,314, issued April 9, 1940.

This invention relates to a method for determining the tectonics of subsurface geology, which comprises reciprocating a magnetic unit adjacent to a drilling bit and in recording the electrical current resulting therefrom. The invention relates also to a method for measuring the inherent terrestrial magnetic flux flowing through the crust of the earth, which comprises reciprocating an electrically charged coil positioned beneath the earth's surface and in continuously recording the electromotive force resulting from the reciprocation of said coil. Claims allowed, 9.

5594. Vorrichtung zum Entnehmen von Proben aus der Seitenwandung eines Bohrloches [Arrangement for taking samples from the side walls of a borehole]; Clarence E. Burt, in Huntington Park, Calif., United States of America: German patent 678,677, issued July 19, 1939.

This invention is characterized by the following arrangement: Levers provided with devices for taking samples-the devices being developed in the form of core barrels-are operated with the aid of a piston by the flow of the rinsing liquid. After the pressure applied for rinsing is turned off, the piston, induced by a spring, moves again upward, thus bringing the lever and the sample-taking device again into their initial position. Claims allowed, 2. 
5595. Kernrohrartiges Geschoss zur Entnahme von Proben aus dem noch nicht verrohrten Teil von Bohrlöchern [Core-barrel-shaped projectile for taking samples from the uncased parts of boreholes]; Société de Prospéction Électrique, Procédés Schlumberger of Paris: German patent 679,275, issued August 2, 1939.

This invention relates to a core-barrel-shaped projectile for taking samples from the walls of the uncased parts of a borehole. The projectile is discharged by means of a shooting device lowered into the borehole. The projectile is closed at both ends, the inside air being pumped out previously, if necessary. The front part of the projectile is closed, for example, with a soldered-on plate which, after the discharge of the projectile, is pressed against the rock. The projectile may be divided by means of a cross wall into two cameras, the connecting opening between which is controlled by a special valve arrangement. Claims allowed, 3.

5596. Verfahren und Vorrichtung zum Bestimmen der Richtung des Streichens, des Fallsinnes und gegebenenfalls des Fallwinkels der von einer Bohrung durchschlagenen Bodenschichten [Method and arrangement for determining the direction of the strike and angle of dip of the layers cut by a borehole]; Société de Prospéction Êlectrique, Procédés Schlumberger in Paris, Henri George Doll of Paris being the inventor: German patent 681,396, issued September 21, 1939.

This invention relates to the method and arrangement of measuring and comparing values of electric fields produced spontaneously in the liquid at various points exactly determined along the line crosswise to the axis of the borehole, and eventually along the borehole, by means enclosed in an apparatus, the position and orientation of which in the borehole is known. Claims allowed, 6 .

5597. Verfahren zum Auffinden der von Bohrlöchern durchschlagenen porösen Schichten [Method for determining porous layers penetrated by boreholes]; Société de Prospéction Électrique, Procédés Schlumberger in Paris: German patent 682,183, issued October 9, 1939.

This invention relates to a method of finding porous layers cut by boreholes and especially for determining the permeability of these layers. The layers are successively saturated with liquids of different constitution, and after the hydrostatic equilibrium has taken place one or several series of electrical measurements are made and values as changed by different constitutions of the liquids are determined. Claims allowed, 1.

5598. Procédé et appareil pour mesurer la température régnant dans un forage [Method and apparatus for measuring temperature in a borehole]; Standard Oil Development Co. of the United States of America: French patent 844,513, issued July 26, 1939.

This invention relates to a method for measuring temperature in a borehole filled with liquid and for measuring temperatures between various points in the borehole. The method consists mainly in exposing a conductor of electrical current to direct contact with the liquid and in observing the impedance of the circuit. The apparatus consists of an electrical conductor arranged so as to allow free exchange of heat between the conductor and the liquid, means for moving the conductor along the borehole, and means for measuring the impedance. Claims allowed, 3. 
5599. Procédé et dispositifs pour l'étude des couches traversées par un sondage, d'après leurs propriétés calorifiques [Method and apparatus for studying the layers traversed by drilling according to their calorific properties]; Société de Prospéction Électrique, Procédés Schlumberger in France: French patent 845,049, issued August 9, 1939.

This invention relates to a method for studying layers traversed by drilling. The method consists in warming up the liquid contained in the borehole and in observing the evolution of the temperature in this liquid. The warming up is accomplished either along the whole height of the borehole, or parts to be investigated are heated only. Variations in temperature of the liquid are studied by means of diagrams of temperatures. The liquid becomes warmer or cooler depending on the conductivity of the layers affected, the thermometric diagrams thus making it possible to obtain indications on the thermal conductivity of these layers. Claims allowed, 3.

5600. Projectile pour la perforation des tubages garnissant la paroi intérieure des sondages [Projectile for the perforation of tubes covering the interior wall of boreholes]; Société de Prospéction Électrique, Procédés Schlumberger of France: French patent 848,335, issued October 26, 1939.

This invention relates to a projectile for perforating the tubed wall of a borehole. It is destined to be projected by means of a known perforation gun of any type. The projectile is provided with a perforating nucleus surrounded by a case having a diameter corresponding to the caliber of the gun, the case being so arranged as to make the dislocating and forcing away of the nucleus possible as soon as the projectile leaves the perforation gun. Claims allowed, 1.

5601. Dispositif pour extraire du sol, des gaz, en particulier de l'air atmosphérique [Apparatus for extracting gas, in particular atmospheric air, from the soil]; Angst, Karl, of France (Seine-et-Marne): French patent 848,600 , issued November 2, 1939.

This invention relates to an arrangement for obtaining gas or similar substances, in particular amospheric air, from the soil. The arrangement is characterized by the fact that the apparatus assigned for the suction of the gas is covered on the surface of the ground by a matter impermeable to the air and of the size of about $6 \mathrm{~m}$. in diameter. Claims allowed, 1. 


\section{INDEX}

[The figure in parentheses refers to the class in which the entry stands; see list in table of contents]

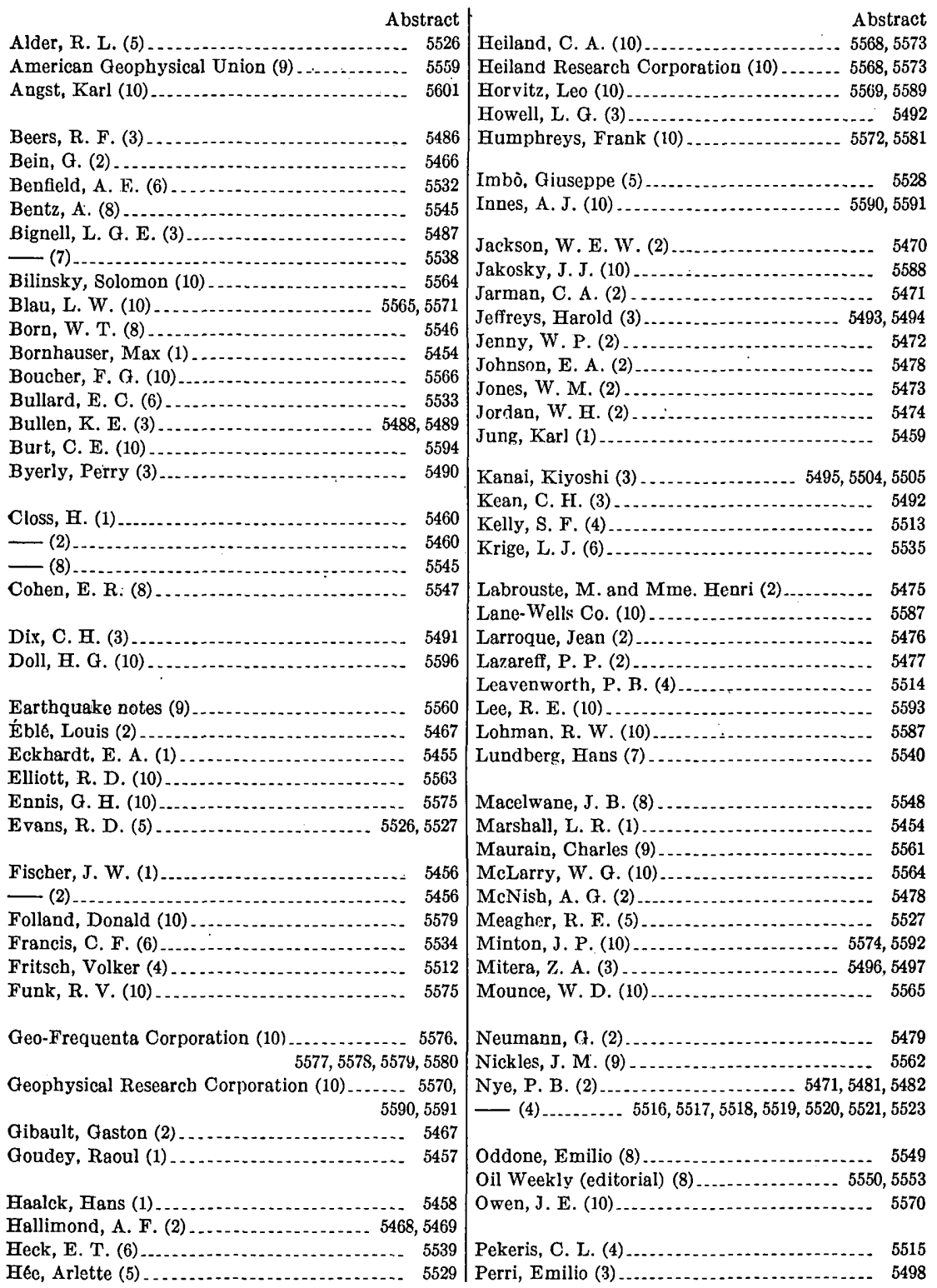




\begin{tabular}{|c|c|}
\hline & \\
\hline 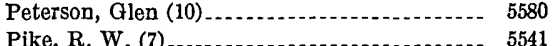 & $\begin{array}{l}\text { Slichter, L. B. (10) } \\
\text { Smertenko, L. (2) }\end{array}$ \\
\hline Pike, R. W. (7) & Smertenko, L. (2) ..... \\
\hline $5577,5578,5579,5582$ & $\begin{array}{r}\text { Société de Prospéction Électrique (10) } \ldots \ldots \ldots .5595 \\
5596,5597,5599,560\end{array}$ \\
\hline & Socony-Vacuum Oil C \\
\hline amirez, J. E. (3) & Specht, Zdzislaw (3).. \\
\hline 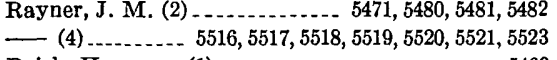 & $\begin{array}{r}\text { Standard OiI Development Co. (10) } \ldots \ldots \ldots 5565 \\
5566,5567,5571,559\end{array}$ \\
\hline eich, Hermann (1) ................ & Stormont, D. H. (7). \\
\hline$-(2) \ldots \ldots \ldots \ldots$ & Strona, A. A. (2)... \\
\hline (1) 5500 & \\
\hline 5522 & 'atge, Eleanor (9) \\
\hline - & Ter \\
\hline A. (2) & Thompson, R. R. (3) \\
\hline G. (3) $\ldots \ldots$ & Thyer, R. F. (4) \\
\hline 250.155 & Todd \\
\hline $\begin{array}{rr}(7) \\
-5564,5569,5589\end{array}$ & Toperczer, Max (3) \\
\hline 5 & Uhrig, L. V. (10) . . \\
\hline (5) & \\
\hline (2) & 5536,553 \\
\hline M. (10) & \\
\hline (n) & \\
\hline (n) & 5462,54 \\
\hline (2) & .... \\
\hline (2.2. & \\
\hline 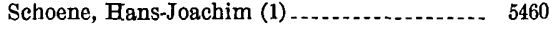 & \\
\hline 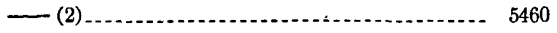 & \\
\hline - & \\
\hline , Conrad (10) & \\
\hline $\begin{array}{l}\text { chlumberger Well Surveying Corporation } \\
(10)\end{array}$ & (n) \\
\hline 55 & $\ldots$ \\
\hline a (3) & (1) \\
\hline (1) & (4) \\
\hline 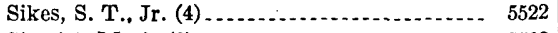 & Wyrobek, St. (3) \\
\hline 5562 & Wyszinski, O. W. (3) \\
\hline & \\
\hline & \\
\hline
\end{tabular}

